\title{
Electronic Cigarette Use and Metabolic Syndrome Development: A Critical Review
}

\author{
Ilona Górna ${ }^{1}\left(\mathbb{D}\right.$, Marta Napierala $^{2}\left(\mathbb{D}\right.$ and Ewa Florek ${ }^{2, *} * \mathbb{( 1 )}$ \\ 1 Department of Bromatology, Poznan University of Medical Sciences, 60-354 Poznan, Poland; \\ igorna@ump.edu.pl \\ 2 Laboratory of Environmental Research, Department of Toxicology, Poznan University of Medical Sciences, \\ 60-631 Poznan, Poland; martan@ump.edu.pl \\ * Correspondence: eflorek@ump.edu.pl; Tel.: +48-61-847-2081
}

Received: 8 September 2020; Accepted: 16 November 2020; Published: 17 November 2020

\begin{abstract}
The metabolic syndrome is a combination of several metabolic disorders, such as cardiovascular disease, atherosclerosis, and type 2 diabetes. Lifestyle modifications, including quitting smoking, are recommended to reduce the risk of metabolic syndrome and its associated complications. Not much research has been conducted in the field of e-cigarettes and the risk of metabolic syndrome. Furthermore, taking into account the influence of e-cigarettes vaping on the individual components of metabolic syndrome, i.e, abdominal obesity, insulin resistance, dyslipidemia and elevated arterial blood pressure, the results are also ambiguous. This article is a review and summary of existing reports on the impact of e-cigarettes on the development of metabolic syndrome as well as its individual components. A critical review for English language articles published until 30 June 2020 was made, using a PubMed (including MEDLINE), Cochrane, CINAHL Plus, and Web of Science data. The current research indicated that e-cigarettes use does not affect the development of insulin resistance, but could influence the level of glucose and pre-diabetic state development. The lipid of profile an increase in the TG level was reported, while the influence on the level of concentration of total cholesterol, LDL fraction, and HDL fraction differed. In most cases, e-cigarettes use increased the risk of developing abdominal obesity or higher arterial blood pressure. Further research is required to provide more evidence on this topic.
\end{abstract}

Keywords: electronic cigarettes; metabolic syndrome; insulin resistance; dyslipidemia; obesity

\section{Introduction}

In the European Union, around 700 thousand people die prematurely each year from the consequences of smoking tobacco [1]. Therefore, it is an important task of health policy to prevent people from taking up smoking and to encourage smokers to quit. Some data indicate that e-cigarettes can be used as a nicotine replacement therapy for smokers, but there is still insufficient evidence to support this hypothesis [1-5].

The basic questions are whether e-cigarettes are safe and whether they can cause chronic diseases. Although research so far has not provided a clear answer to these questions, experts believe that the negative effects of e-cigarettes use can only become apparent after many years. Initially, e-cigarettes were not subject to legal regulations, which resulted in significant inconsistencies in their composition (concentration of nicotine, tobacco-specific nitrosamines (TSNAs), heavy metals, polycyclic aromatic hydrocarbon (PAHs), other toxic and carcinogenic substances specific for tobacco) [6-8]. The currently applicable directive is more restrictive as for their composition [9]. Nevertheless, many other ingredients and supplements (such as vitamin E) that appear in e-cigarettes and their influence on human health 
have not been sufficiently studied. This, in turn, does not allow to explicitly affirm the safety of e-cigarettes [10].

Metabolic syndrome (MetS) is becoming more and more common among the citizens of highly developed Western countries. The results of a meta-analysis conducted by Sun et al. [11] indicate a clear connection between tobacco smoking and the risk of MetS. Based on data gathered in 13 prospective cohort studies (56,691 participants; 8688 cases of MetS), active tobacco smokers are at a $26 \%$ higher risk of MetS than nonsmokers [11]. In turn, there is still not much known about the influence of e-cigarettes use on the risk of developing MetS.

The present paper constitutes an overview and summary of the research reports so far on the topic of the influence of e-cigarettes on the development of MetS as well as its individual components. Moreover, the authors compared the actual knowledge about the impact of e-cigarettes use and smoking of conventional cigarettes (tobacco) on MetS.

\section{Methodology}

A critical review for 264 English language articles published until 30 June 2020 was made, using PubMed (including MEDLINE), CINAHL Plus, Cochrane, and Web of Science data. Twenty-three of these scientific papers were directly related to studies on e-cigarettes and the MetS and its individual components. Among them, 1 described an in vitro and animal study, 6 were experimental studies using animal models, and 16 studies concern the impact of e-cigarettes on their users. The literature search was performed using MESH terms and other relevant keywords. The key search terms were "electronic cigarettes", "tobacco smoking" and "metabolic syndrome", "insulin resistance", "diabetes", "dyslipidemia", "obesity", "blood pressure" (Table 1). Technical reports, expert statements, recommendations, other non-original papers as well as preprints and conference papers were excluded from our review. All of the presented original papers studies were peer-reviewed.

Table 1. Search strategy.

\begin{tabular}{ll}
\hline & (i) $\begin{array}{l}\text { To assess the contribution of existing literature of association of electronic } \\
\text { cigarette use and metabolic syndrome development as well as its } \\
\text { individual components (insulin resistance, diabetes, dyslipidemia, obesity, } \\
\text { blood pressure). } \\
\text { Objectives }\end{array}$ \\
& (ii) $\begin{array}{l}\text { To compare the impact of e-cigarettes use and smoking conventional } \\
\text { cigarettes on metabolic syndrome }\end{array}$ \\
& (iii) To identify relevant information and outline existing knowledge \\
(iv) To identify any gap in the existing research
\end{tabular}

\section{E-Cigarettes and Metabolic Syndrome}

Metabolic syndrome among adults is diagnosed when three of the five following factors are present: abnormal waist circumference (depending on population group), triglyceride concentration $(\geq 150 \mathrm{mg} / \mathrm{dl}$ or implemented hypolipidemic treatment), HDL cholesterol concentration $(<40 \mathrm{mg} / \mathrm{dl} \mathrm{men,}<50 \mathrm{mg} / \mathrm{dl}$ women or implemented treatment), arterial pressure ( $\geq 130 / 85$ or implemented hypotensive treatment), 
glycaemia ( $\geq 100 \mathrm{mg} / \mathrm{dl}$ or implemented hypoglycemic treatment). Furthermore, the International Diabetes Federation (IDF) proposed definitions of the MetS adapted to three age groups of minors: 6-10 years, 10-16 years, and over 16 years of age. According to the IDF guidelines, the diagnosis of MetS should not be made in children under 10 years of age. However, if the child is obese and the accumulation of adipose tissue occurs mainly around the waist, it is advisable to take intensive measures aimed at weight reduction. In children over 10 years of age, according to the IDF guidelines, MetS can be diagnosed when abdominal obesity is present (waist circumference above the 95th percentile for a given child's age) and the presence of at least two factors: elevated triglyceride, decreased HDL-C levels—same for both sexes, increased blood pressure, increased fasting glucose. In clinical practice, adolescents over 16 years of age use the adult MetS criteria [12-18].

MetS is diagnosed in 1/4 of the adult population worldwide [13]. Simultaneously, an increase in the number of cases among younger people has been observed in the last couple of years, especially in developing countries [14]. Research results indicate that MetS occurs in obese (60\%) and overweight people $(22 \%)$, but also in people with correct body weight (5\%) [15]. In order to minimize the risk and complications of MetS, it is advisable to modify one's lifestyle, increase physical activity, and quit smoking. Moreover, it has been demonstrated that the odds ratio of occurrence of MetS decreases with time, once the person has quit smoking $[19,20]$.

The influence of smoking conventional cigarettes on the occurrence of MetS has been the subject of research for many years. The first mentions that some features of MetS stem from the smoking addiction that appeared in 1998 [21]. Since then, the results of numerous studies have pointed to an increase in the risk of developing MetS in active and second-hand tobacco smokers [22-28]. As studies have revealed, nicotine has the ability to inhibit lipogenesis, increase lipolysis as well as the amount of free fatty acids, which leads to the development of insulin resistance and type 2 diabetes mellitus. [29-35]. The risk assessment of occurrence of serious metabolic effects in the case of e-cigarettes use has not been thoroughly analyzed yet. However, taking into account current in vitro and in vivo studies using animal models, we can claim that even those e-cigarettes, which do not contain nicotine, can contribute to the changes in body weight, lipid profile, hyperglycemia, as well as in the level of oxidative stress $[29,30,33]$.

So far, there have been very few publications demonstrating the influence of e-cigarettes on the risk of occurrence of MetS in people (Table 2). Research on a group of 18,300 volunteers was conducted by Lequy et al. [36]. The obtained results allowed the researchers to claim that the occurrence of MetS was connected with using e-cigarettes, whenever patients were not on a diet. Another study [37] has been conducted on a group of 7505 Korean males over 19 years of age to compare the frequency of occurrence of cardiovascular risk factors among: males smoking conventional cigarettes, dual users (e-cigarettes and traditional cigarettes users) and never-smokers. The multivariate logistic regression analysis showed that, in the adjusted model, the odds ratio (OR) for the prevalence of MetS equaled $2.79(p<0.001)$ in comparison with never-smokers and $1.57(p=0.038)$ in relation to cigarette-only smokers [37]. In this model, dual users were characterized by an increased waist circumference and TG level, as well as reduced HDL in comparison with both the people who had never smoked and those who smoked only traditional cigarettes [37]; therefore, it may be concluded that dual users are more vulnerable to cardiovascular risk factors. 
Table 2. The impact of electronic cigarettes use and tobacco smoke exposure on MetS.

\begin{tabular}{|c|c|c|c|c|c|}
\hline Type of Study & $\begin{array}{c}\text { Participants/ } \\
\text { Rodents/ } \\
\text { Type of Cells }\end{array}$ & Country & $\begin{array}{c}\text { Exposure } \\
\text { Assessment }\end{array}$ & Results & Reference \\
\hline \multicolumn{6}{|c|}{ E-CIGARETTES } \\
\hline Human & $\begin{array}{l}\text { Participants of the } \\
\text { constancies cohort } \\
(n=18,300, \\
\text { aged 18-96 years), } \\
\text { current users of } \\
\text { e-cigarette and } \\
\text { current or } \\
\text { ex-smokers of } \\
\text { tobacco. }\end{array}$ & France & Questionnaire & $\begin{array}{c}\text { Increased risk } \\
\text { of MetS } \\
\text { associated with } \\
\text { e-cigarette use } \\
\text { only when not } \\
\text { on a diet, } \\
p<0.05 .\end{array}$ & Lequy et al. [36] \\
\hline Human & $\begin{array}{c}\text { Male participants } \\
(n=7505, \\
\text { aged } 19 \text { years or } \\
\text { older), users of } \\
\text { e-cigarette or tobacco } \\
\text { or dual users. }\end{array}$ & Republic of Korea & $\begin{array}{l}\text { Urinary } \\
\text { cotinine }\end{array}$ & $\begin{array}{l}\text { No differences, } \\
\text { however in the } \\
\text { adjusted model } \\
\text { odds ratio for } \\
\text { MetS was } 2.79 \\
(p<0.001) \\
\text { compared with } \\
\text { never smokers } \\
\text { and } 1.57 \\
(p=0.038) \\
\text { compared with } \\
\text { cigarette-only } \\
\text { smokers. }\end{array}$ & Kim et al. [37] \\
\hline Human & $\begin{array}{c}\text { Participants } \\
(n=17,656, \\
\text { aged } 20-70 \text { years), } \\
\text { data from the Korea } \\
\text { National Health and } \\
\text { Nutrition } \\
\text { Examination Survey, } \\
\text { tobacco or dual } \\
\text { users. }\end{array}$ & Republic of Korea & Questionnaire & $\begin{array}{c}\text { Increased risk } \\
\text { of MetS among } \\
\text { women and } \\
\text { among men } \\
\text { using packet of } \\
\text { cigarettes for } \\
20 \text { years or } \\
\text { more, OR } 4.02 \text {, } \\
95 \% \text { CI } \\
1.48-10.93 .\end{array}$ & Oh et al. [38] \\
\hline \multicolumn{6}{|c|}{ TOBACCO SMOKE } \\
\hline In vitro-cells & $\begin{array}{c}\text { Mouse embryo } \\
\text { 3T3-L1 } \\
\text { pre-adipocytes } \\
\text { (ATCC }{ }^{\circledR} \text { CL-173 }{ }^{\mathrm{TM}} \\
\text { ATCC, Manassas, } \\
\text { VA, USA). }\end{array}$ & United States & $\begin{array}{l}\text { Exposure to } \\
\text { cigarette smoke, } \\
\text { electronic } \\
\text { cigarettes, } \\
\text { and heated } \\
\text { tobacco } \\
\text { products. }\end{array}$ & $\begin{array}{c}\text { Increased } \\
\text { metabolic } \\
\text { activity after } \\
24 \mathrm{~h}(p<0.05) \\
\text { and } 48 \mathrm{~h} \\
(p<0.01) \text { of } \\
\text { treatment of } \\
\text { tobacco smoke. }\end{array}$ & Zagoriti et al. [33] \\
\hline Animal & $\begin{array}{l}\text { Male Wistar rats } \\
\text { (young adults). }\end{array}$ & Jordan & $\begin{array}{l}\text { Exposure to } \\
\text { waterpipe } \\
\text { tobacco smoke. }\end{array}$ & $\begin{array}{c}\text { Increased risk } \\
\text { of MetS - } \\
\text { abdominal } \\
\text { circumference } \\
(p<0.0001) \\
\text { body weight } \\
(p=0.02) \\
\text { systolic blood } \\
\text { pressure } \\
(p<0.0001) \\
\text { fasting blood } \\
\text { glucose } \\
(p<0.0001) .\end{array}$ & Al-Sawalha et al. [22] \\
\hline Human & $\begin{array}{l}\text { Male participants } \\
\quad(n=5697, \\
\text { aged } 26-75 \text { years }) .\end{array}$ & Japan & Questionnaire & $\begin{array}{c}\text { Increased risk } \\
\text { of MetS } p<0.05 \\
\text { compared with } \\
\text { nonsmokers. }\end{array}$ & Matsushita et al. [20] \\
\hline
\end{tabular}


Table 2. Cont.

\begin{tabular}{|c|c|c|c|c|c|}
\hline Type of Study & $\begin{array}{l}\text { Participants/ } \\
\text { Rodents/ } \\
\text { Type of Cells }\end{array}$ & Country & $\begin{array}{l}\text { Exposure } \\
\text { Assessment }\end{array}$ & Results & Reference \\
\hline \multicolumn{6}{|c|}{ TOBACCO SMOKE } \\
\hline Human & $\begin{array}{c}\text { Participants } \\
(n=3051, \\
\text { aged 20-60 years). }\end{array}$ & United States & Questionnaire & $\begin{array}{c}\text { Increased risk } \\
\text { of MetS: } \\
\text { each year } \\
\text { increase in } \\
\text { cigarette } \\
\text { smoking, } \\
\text { odds ratio ( } 95 \% \\
\text { CI), } 1.00(0.99, \\
1.02), \text { between } \\
\text { current smoker } \\
\text { or past, } 1.51 \\
(0.80,2.87) \text { vs. } \\
1.64(0.97,2.79) .\end{array}$ & Yankey et al. [23] \\
\hline Human & $\begin{array}{c}\text { Participants } \\
(n=2212 \\
\text { aged } 30-49 \text { years })\end{array}$ & Venezuela & Questionnaire & $\begin{array}{c}\text { Increased risk } \\
\text { of MetS } \\
p<0.001 \\
\text { compared with } \\
\text { nonsmokers, } \\
\text { in the } \\
\text { multivariate } \\
\text { analysis: } \\
\text { smokers: OR, } \\
1.54 ; 95 \% \mathrm{CI} \\
1.11-2.14 \\
p=0.010 . \\
\end{array}$ & Bermudez et al. [24] \\
\hline Human & $\begin{array}{c}\text { Participants } \\
(n=694 \\
\text { aged 18-44 years). }\end{array}$ & Taiwan & Questionnaire & $\begin{array}{c}\text { Increased risk } \\
\text { of MetS males } \\
\text { higher MetS } \\
\text { prevalence than } \\
\text { females } \\
p<0.001 .\end{array}$ & Lin et al. [26] \\
\hline Human & $\begin{array}{c}\text { Participants } \\
(n=430, \\
\text { aged } 22.52 \pm 0.40 \text { years }) .\end{array}$ & Chile & Questionnaire & $\begin{array}{c}\text { Increased risk } \\
\text { of MetS, linear } \\
\text { regression } \\
\text { model: MetS } \\
\text { score } p<0.02 \text {. }\end{array}$ & Cheng et al. [27] \\
\hline Human & $\begin{array}{c}\text { Participants } \\
(n=1637 \\
\text { aged } 70.5-7.9 \text { years }) .\end{array}$ & Colombia & Questionnaire & 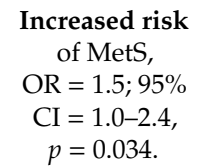 & $\begin{array}{c}\text { Barranco-Ruiz et al. } \\
\text { [28] }\end{array}$ \\
\hline
\end{tabular}

In the newest study presented by Oh et al. [38], the type of smoking (conventional ones versus dual users) on the risk of the occurrence of MetS was assessed as well as its relation with the sex of the examined persons. The analysis of smoking history involved 5462 cases of MetS and a control group of 12,194 people. The obtained results demonstrated a lack of influence of the smoking kind on the occurrence of MetS among men as well as among women. However, the increase in the risk of the occurrence of MetS was related to smoking a packet of cigarettes for 20 years or more [38].

\section{Insulin Resistance}

Insulin resistance (IR) is the main pathogenic factor in type 2 diabetes mellitus, prediabetic state, as well as lipodystrophy [39]. There are many causes of insulin resistance, the main one being excessive body weight. Research results suggest that values of waist circumference over $94 \mathrm{~cm}$ in men and $80 \mathrm{~cm}$ in women belong to the first symptoms of insulin resistance. Frequently, the accompanying symptoms include increased fasting blood glucose level, arterial hypertension, and hyperlipidemia [39,40]. 
Studies have shown that nicotine causes decreased sensitivity of tissues to insulin, thus increasing the risk of developing type 2 diabetes mellitus [41]. Nicotine contributes to an increase in the level of hormones antagonistic to insulin, i.e, catecholamines and cortisol [42]. In turn, research studies conducted on animals have shown a direct influence of nicotine on activation of protein kinase dependent on AMP in adipose tissue. It increased the speed of lipolysis and promoted insulin resistance [32]. Insulin resistance, which causes the development of diabetes mellitus, is connected with prothrombotic inflammatory conditions and provokes atherogenic changes in blood lipids. It increases the risk of ischemic heart disease, diseases of peripheral arteries, and brain stroke [43].

The research conducted by Orimoloye et al. [44] concerned electronic cigarettes and insulin resistance in animals and humans. Their results were based on a controlled animal study and the National Health and Nutrition Examination Survey (NHANES 2013-2016) that involved 3989 participants. The assessed criterion was the influence of tobacco smoking and e-cigarettes use on the occurrence of insulin resistance, modelled with the use of homeostasis model assessment-insulin resistance (HOMA-IR) and glucose tolerance test (GTT). Research conducted on C57BL6/J mice exposed to e-cigarette aerosol or mainstream cigarette smoke for 12 weeks did not demonstrate any significant differences in comparison to the control group (filtered air) [44]. An analysis of the NHANES data also demonstrated no correlation between decreased sensitivity of tissues to insulin and different types of smokers (conventional cigarettes smokers, e-cigarettes users, dual users and nonsmokers) [44]. A lack of significant differences in the level of glucose was demonstrated also by Kim et al. [37] in their aforementioned study.

Research on the influence of nicotine on the organism has demonstrated its ability to induce hyperglycemia by activating glycogenesis and gluconeogenesis [45]. El Golli et al. [46] conducted experiment on rats administered intraperitoneally exposed to pure nicotine $(0.5 \mathrm{mg} / \mathrm{kg}$ of body weight), e-liquid with or without nicotine during 28 days [46], and a significant increase in the level of blood glucose was reported. Additionally, a reduced level of liver proteins and increased transaminase activity were detected in all the examined groups, yet it was the rats exposed to e-cigarettes which achieved worse results than the rats exposed to pure nicotine. It can suggest that the mechanism of disorders of glucose metabolism induced by e-cigarettes is different than in the case of nicotine alone [46].

Also, the connection between e-cigarettes use and prediabetic states has to be borne in mind. Research within this field has been conducted by Atuegwu et al. [35] among a group of people who are currently e-cigarettes users, those who used them in the past, and never-users. It was demonstrated that the current e-cigarettes users were at a greater risk of being diagnosed with prediabetic state than those who had never used this kind of cigarettes. Importantly, no relationship was reported between being a former e-cigarette user and prediabetic state [35] (Table 3).

Table 3. The impact of electronic cigarettes use and tobacco smoke exposure on insulin resistance and diabetes.

\begin{tabular}{|c|c|c|c|c|c|}
\hline Type of Study & $\begin{array}{l}\text { Participants/ } \\
\text { Rodents/ } \\
\text { Type of Cells }\end{array}$ & Country & $\begin{array}{c}\text { Exposure } \\
\text { Assessment }\end{array}$ & Results & Reference \\
\hline \multicolumn{6}{|c|}{ E-CIGARETTES } \\
\hline Animal & C57BL6/J mice & United States & $\begin{array}{l}\text { Exposure to } \\
\text { e-cigarette } \\
\text { aerosol or } \\
\text { mainstream } \\
\text { cigarette smoke } \\
\text { comparable } \\
\text { with filtered } \\
\text { air-exposed } \\
\text { controls. }\end{array}$ & $\begin{array}{l}\text { No differences } \\
\text { of insulin } \\
\text { resistance } \\
\text { Modelled using } \\
\text { the homeostatic } \\
\text { model } \\
\text { assessment of } \\
\text { insulin } \\
\text { resistance } \\
\text { (HOMA-IR) } \\
\text { and glucose } \\
\text { tolerance tests, } \\
\text { Glucose } \\
\text { tolerance tests } \\
p=0.17 .\end{array}$ & Orimoloye et al. [44] \\
\hline
\end{tabular}


Table 3. Cont.

\begin{tabular}{|c|c|c|c|c|c|}
\hline Type of Study & $\begin{array}{l}\text { Participants/ } \\
\text { Rodents/ } \\
\text { Type of Cells }\end{array}$ & Country & $\begin{array}{c}\text { Exposure } \\
\text { Assessment }\end{array}$ & Results & Reference \\
\hline \multicolumn{6}{|c|}{ E-CIGARETTES } \\
\hline Animal & Male Wistar rats & Tunisia & $\begin{array}{l}\text { E-liquid with or } \\
\text { without } \\
\text { nicotine and } \\
\text { nicotine alone } \\
(0.5 \mathrm{mg} / \mathrm{kg} \text { of } \\
\text { body weight }) \\
\text { were } \\
\text { administered } \\
\text { intraperitoneally } \\
\text { during } 28 \text { days. }\end{array}$ & $\begin{array}{c}\text { Increased risk } \\
\text { of diabetes } \\
\text { Plasma glucose, } \\
\quad p<0.05 .\end{array}$ & El Goli et al. [46] \\
\hline Human & $\begin{array}{c}\text { Participants } \\
(n=154,404 \\
\text { aged }>18 \text { years })\end{array}$ & United States & Questionnaire & $\begin{array}{c}\text { Increased risk } \\
\text { of } \\
\text { diabetestested } \\
\text { blood glucose } \\
\text { in past } 3 \text { years, } \\
\text { history of } \\
\text { prediabetes, } \\
\text { compared to } \\
\text { never } \\
\text { e-cigarette } \\
\text { users 1.97 (95\% } \\
\text { CI, 1.25-3.10) } \\
\text { for current } \\
\text { e-cigarette } \\
\text { users, and } 1.07 \\
\text { (95\% CI, } \\
0.84-1.37) \text { for } \\
\text { former } \\
\text { e-cigarette } \\
\text { users. }\end{array}$ & Atuegwu et al. [35] \\
\hline Human & $\begin{array}{l}\text { Male participants } \\
\qquad(n=7505 \\
\text { aged }>19 \text { years })\end{array}$ & Republic of Korea & $\begin{array}{l}\text { Urinary } \\
\text { cotinine }\end{array}$ & $\begin{array}{c}\text { No differences } \\
\text { Fasting plasma } \\
\text { glucose, } \\
p>0.05\end{array}$ & Kim et al. [37] \\
\hline \multicolumn{6}{|c|}{ TOBACCO SMOKE } \\
\hline Animal & $\begin{array}{l}\text { Male C57BL/6J mice } \\
\quad(8 \text { week old }) .\end{array}$ & China & $\begin{array}{c}\text { Low dosages of } \\
\text { nicotine } \\
(0.8 \mathrm{mg} / \mathrm{kg} / \mathrm{d}), \\
\text { high dosages of } \\
\text { nicotine } \\
(4 \mathrm{mg} / \mathrm{kg} / \mathrm{d}), \\
\text { or saline } \\
\text { (vehicle) using } \\
\text { Alzet osmotic } \\
\text { pumps. }\end{array}$ & $\begin{array}{l}\text { Increased risk } \\
\text { of insulin } \\
\text { resistance } \\
\text { Serum insulin, } \\
\quad p<0.05 .\end{array}$ & Wu et al. [32] \\
\hline Human & $\begin{array}{c}\text { Participants } \\
\quad(n=5931 \\
\text { aged } 45-84 \text { years }) .\end{array}$ & Multi- Ethnic Study & $\begin{array}{l}\text { Self-reported } \\
\text { tobacco status } \\
\text { and reclassified } \\
\text { by urinary } \\
\text { cotinine. }\end{array}$ & $\begin{array}{l}\text { No differences } \\
\text { of insulin } \\
\text { resistance } \\
\text { Insulin } \\
\text { resistance } \\
\text { biomarkers } \\
p>0.10 \\
\text { No differences } \\
\text { of plasma } \\
\text { glucose } \\
\text { Fasting plasma } \\
\text { glucose, } \\
p>0.05 .\end{array}$ & Keith et al. [47] \\
\hline Human & $\begin{array}{c}\text { Participants } \\
(n=12 \\
\text { aged } 54 \pm 10 \text { years, } \\
\text { diabetic) }\end{array}$ & Sweden & $\begin{array}{l}\text { Nicotine } 0.3 \\
\mu \mathrm{g} / \mathrm{kg} / \mathrm{min} \text { or } \\
\mathrm{NaCl} \text { was } \\
\text { infused }(2 \mathrm{~h}) \\
\text { during a } \\
\text { euglycemic } \\
\text { hyperinsulinemia } \\
\text { clamp }(4 \mathrm{~h}) .\end{array}$ & $\begin{array}{c}\text { Increased risk } \\
\text { of insulin } \\
\text { resistance, } \\
\text { plasma insulin } \\
p<0.0001 \\
\text { Increased risk } \\
\text { of diabetes } \\
\text { Plasma glucose } \\
p=0.0039 .\end{array}$ & Axelsson et al. [48] \\
\hline
\end{tabular}


Table 3. Cont.

\begin{tabular}{|c|c|c|c|c|c|}
\hline Type of Study & $\begin{array}{l}\text { Participants/ } \\
\text { Rodents/ } \\
\text { Type of Cells }\end{array}$ & Country & $\begin{array}{c}\text { Exposure } \\
\text { Assessment }\end{array}$ & Results & Reference \\
\hline \multicolumn{6}{|c|}{ TOBACCO SMOKE } \\
\hline Human & $\begin{array}{c}\text { Review-25 } \\
\text { prospective cohort } \\
\text { studies. }\end{array}$ & & & $\begin{array}{c}\text { Increased risk } \\
\text { of diabetes } \\
24 \text { reported } \\
\text { adjusted RRs } \\
\text { greater than } 1 \\
\text { (range for all } \\
\text { studies, } \\
0.82-3.74) . \\
\text { The pooled } \\
\text { adjusted RR } \\
\text { was } 1.44(95 \% \\
\text { confidence } \\
\text { interval (CI), } \\
\text { 1.31-1.58). }\end{array}$ & Willi et al. [31] \\
\hline Human & $\begin{array}{c}\text { Participants } \\
\quad(n=3051 \\
\text { aged 20-60 years). }\end{array}$ & United States & Questionnaire & $\begin{array}{c}\text { Increased risk } \\
\text { of diabetes } \\
\text { Fasting plasma } \\
\text { glucose } \\
p<0.001 .\end{array}$ & Yankey et al. [23] \\
\hline
\end{tabular}

\section{Dyslipidemia}

In the first phase of development of many cardiovascular diseases, hyperglycemia leads to damage to endothelium cells [49]. It is known that elevated glucose and insulin levels as well as insulin resistance can contribute to the development of atherosclerosis also through dyslipidemia, hypertension and inflammatory condition [50]. Increasing oxidative stress has an inhibitory effect on the availability of nitrogen oxide and creates advanced final products of glycation, which are significantly related to the risk factors of coronary disease and can favor its development [50]. Smoking cigarettes, obesity and IR influence a reduction in nitrogen oxide bioavailability. In turn, its elevated concentration diminishes adipose mass, concentration of glucose, triglycerides, free fatty acids and leptin in blood serum, increases mass of skeletal muscles and brown adipose mass [51]. Lipid disorders connected with insulin resistance manifest themselves mainly with elevated concentration of triglycerides (TG) and low concentration of HDL fraction cholesterol. Such abnormalities in the lipid profile contribute to an increased cardiovascular risk [40].

Numerous studies on the influence of smoking traditional cigarettes have revealed that higher concentrations of total cholesterol, TG, and LDL are reported in smokers, while a decrease in HDL fraction occurs $[23,52,53]$. Researchers link this correlation to a decreased activity of lipoprotein lipase and cholesterol acetyltransferase in plasma caused by smoking, as well as to an increased amount of free fatty acids. However, no changes in the influence on liver lipase have been reported [34]. Research has also demonstrated that nicotine causes redistribution of lipids and ectopic deposition of adipose tissue, thanks to which too-high TG concentration in the liver and blood serum leads to fatty liver [32]. Moreover, research conducted on mice which were given nicotine injections twice a day combined with a high-fat diet demonstrated an increase in oxidative stress, apoptosis activation and fatty liver [54].

Very significant research from the point of view of the influence of e-cigarettes on the state of the liver were conducted on mice by Hasan et al. [55]. The apolipoprotein E-deficient (ApoE-/-) mice were used in the study, because they develop fatty liver when fed a Western-type diet (Western Diet: $0.21 \%$ cholesterol, $21 \% \mathrm{kcal}$ from fat, $50 \% \mathrm{kcal}$ from carbohydrates and $20 \% \mathrm{kcal}$ from proteins) at $45 \%$ of calories coming from fat. Moreover, this innovative model had all the features characteristic of nonalcoholic fatty liver disease as well as of MetS [55]. The mice were exposed to e-cigarettes and saline solution. The research results demonstrated that e-cigarettes caused an increased accumulation of lipids of diverse size in hepatocytes, while the number of cell organelles was reduced. Additionally, a significant increase in TG in the liver was reported [55]. Further research confirmed that e-cigarettes 
use led to NAD+ deficits. It was established that it can suggest a mechanistic relationship between damage to liver DNA caused by this type of cigarettes and mitochondrial dysfunction [56]. Similar results indicating a negative influence of e-cigarettes were obtained by El Golli et al. [57] in research conducted on rats treated for 28 days with intraperitoneal injections of pure saline solution, e-liquid without nicotine, e-liquid with nicotine content $(0.5 \mathrm{mg} / \mathrm{kg}$ of body weight), and pure nicotine $(0.5 \mathrm{mg} / \mathrm{kg}$ of body weight), which were diluted in saline solution. The analysis of the obtained results demonstrated lower oxidative stress and fewer histopathological disorders in the case of pure nicotine injections than in the case of e-liquids with nicotine. Furthermore, the authors observed increased activities of the liver biomarkers (aspartate aminotransferase, alanine aminotransferase, alkaline phosphatase, and lactate dehydrogenase) and identified inflammatory cells infiltration and cell death in the group exposed to e-liquid without nicotine. Therefore, they suggested that even e-liquids without nicotine can cause damage to the liver, and the addition of nicotine can enhance their adverse impact [57].

Also in another study, El Golli et al. [46] demonstrated that rats exposed for 28 days to e-cigarettes (both those containing nicotine: $0.5 \mathrm{mg} / \mathrm{kg}$ of body weight and those without it) showed significantly lower content of total cholesterol (TC) as well as of its LDL fraction in comparison to the group exposed to nicotine alone. Exposure to pure nicotine, in turn, caused an increase in TG in comparison with the other examined groups. In the case of the HDL fraction cholesterol, no reduction in comparison with the control group was reported, as opposed to the group exposed to nicotine, in which a decrease in HDL concentration was reported. The authors also demonstrated a significant increase in the TG/HDL ratio in the case of exposure to nicotine. In turn, for the TC/HDL and LDL/HDL ratios, lower values were reported during exposure to e-cigarettes, irrespective of whether they contained nicotine or not [46]. The authors point to the fact that, on the one hand, the improvement in lipid profile suggests a protective effect of e-liquid from e-cigarettes, yet on the other, they indicate that e-cigarettes can modify cholesterol content and thus influence hepatic function [46]. Due to the above, also liver biomarkers were subjected to an analysis. The analysis demonstrated a lower level of liver proteins as well as a higher alkaline phosphatase transaminases activity in all the examined groups, yet it was the rats exposed to e-cigarettes that showed greater deviations than those exposed to nicotine. The authors suggest that the abnormalities in the activity of liver enzymes are connected to damages to hepatocytes caused by e-cigarettes and nicotine [46].

It is also worth emphasizing that oxidative stress is of great significance. In case of its increase, the susceptibility of LDL fraction cholesterol to oxidation increases. Research conducted by Moheimani et al. [58] demonstrated an increase in oxidative stress in a group of persons who used e-cigarettes as opposed to nonsmokers. In turn, research conducted by Lerner et al. [59] reported similar reactivity of reactive oxygen species in e-cigarettes and cigarette smoke. Yet another study suggests that the level of oxidative stress can depend on the kind of liquid used in e-cigarettes. Having examined 11 liquids, the researchers concluded that only 1 was characterized by a significant increase in oxidative stress in human epithelium cell cultures [60]. However, it is worth highlighting that there is a great probability that the ingredients of liquids used in e-cigarettes will result in an increase in the number of reactive oxygen species once heated [58].

In their research on the myocardial infarction risk factors, Alzahrani et al. [61] analyzed electronic and traditional cigarettes. The participants of the study were nonsmokers, exsmokers, persons smoking from time to time, and daily smokers. Daily e-cigarette use as well as daily conventional cigarette smoking was independently associated with increased odds of having had a myocardial infarction. The authors demonstrated that odds of a myocardial infarction increased with elevated cholesterol concentration, occurrence of hypertension, and type 2 diabetes mellitus, as well as with age and sex. Although this study looked at risk factors for myocardial infarction, the relationship between e-cigarette smoking and increased cholesterol level, hypertension, and type 2 diabetes may be important for the risk of developing MetS [61]. 
Also, research conducted by Badea et al. [62] confirms the fact that e-cigarettes influence the lipid profile. A comparison between nonsmokers, people smoking traditional cigarettes, and those using e-cigarettes demonstrated that the LDL fraction concentration was significantly higher in the group smoking e-cigarettes than in the control group, as opposed to those smoking traditional cigarettes, in whose case a negligible increase was reported. The concentration of total cholesterol increased in all the groups of smokers, and despite the fact that no significant differences were demonstrated between them and the non-smoking group, a higher median value was reported in the group of people vaping e-cigarettes. In both groups also a slight decrease in the HDL fraction cholesterol was reported in comparison with the nonsmoking group, yet this decrease was greater in the group of people smoking e-cigarettes. In turn, in the case of VLDL, the group of e-cigarettes users demonstrated a smaller increase in its concentration in blood serum [62] (Table 4).

Table 4. The impact of electronic cigarettes use and tobacco smoke exposure on dyslipidemia.

\begin{tabular}{|c|c|c|c|c|c|}
\hline Type of Study & $\begin{array}{l}\text { Participants/ } \\
\text { Rodents/ } \\
\text { Type of Cells }\end{array}$ & Country & $\begin{array}{l}\text { Exposure } \\
\text { Assessment }\end{array}$ & Results & Reference \\
\hline \multicolumn{6}{|c|}{ E-CIGARETTES } \\
\hline Animal & Male Wistar rats & Tunisia & $\begin{array}{l}\text { E-liquid with or } \\
\text { without nicotine } \\
\text { and nicotine alone } \\
\text { ( } 0.5 \mathrm{mg} / \mathrm{kg} \text { of body } \\
\text { weight) } \\
\text { administered } \\
\text { intraperitoneally } \\
\text { during } 28 \text { days. }\end{array}$ & $\begin{array}{c}\text { No differences of } \\
\text { plasma HDL } \\
p>0.05 \\
\text { Increase of plasma } \\
\text { TG, } p<0.05 \\
\text { Decrease of plasma } \\
\text { LDL, } p<0.01 ; \\
\text { Decrease of plasma } \\
\text { total cholesterol, } \\
p<0.0001\end{array}$ & El Goli et al. [46] \\
\hline Human & $\begin{array}{l}\text { Participants }(n=150, \\
\text { middle aged) }\end{array}$ & Romania & $\begin{array}{l}\text { Self-reports of the } \\
\text { participants. }\end{array}$ & $\begin{array}{c}\text { Decrease of plasma } \\
\text { HDL, } p>0.05 \\
\text { Increase of plasma } \\
\text { LDL, } p<0.05 \\
\text { Increase of plasma } \\
\text { total cholesterol, } \\
\quad p>0.05\end{array}$ & Badea et al. [62] \\
\hline \multicolumn{6}{|c|}{ TOBACCO SMOKE } \\
\hline Animal & $\begin{array}{c}\text { The human CETP } \\
\text { transgenic mice } \\
(\text { C57BL/6) }\end{array}$ & China & $\begin{array}{l}\text { Exposure to either } \\
\text { room air or cigarette } \\
\text { smoke at five } \\
\text { cigarettes/d and } 5 \\
\text { d/wk for } 12 \text { weeks }\end{array}$ & $\begin{array}{c}\text { Decrease of plasma } \\
\text { HDL, } p<0.05 \\
\text { Increase of plasma } \\
\text { LDL, } p<0.01\end{array}$ & Zong et al. [53] \\
\hline Human & Review & & & $\begin{array}{l}\text { Decrease of plasma } \\
\text { HDL- is the most } \\
\text { widely documented } \\
\text { lipid abnormality } \\
\text { related to smoking; } \\
\text { Increase of plasma } \\
\text { total cholesterol. }\end{array}$ & Athyros et al. [52] \\
\hline Human & $\begin{array}{c}\text { Participants } \\
\quad(n=3051, \\
\text { aged } 20-60 \text { years })\end{array}$ & United States & Questionnaire & $\begin{array}{l}\text { Decrease of plasma } \\
\text { HDL, } p<0.01 \\
\text { Increase of plasma } \\
\text { TG, } p<0.001 \\
\text { Increase of plasma } \\
\text { LDL, } p<0.01\end{array}$ & Yankey et al. [23] \\
\hline
\end{tabular}




\section{Abdominal Obesity}

Obesity is characterized by an increase in body weight caused by a rise in the amount of adipose tissue (in men above $25 \%$, in women above $30 \%$ of body weight) [63]. Adipose tissue does not only act as reserve supplies for the organism, but is also a source of bioactive agents, such as adipokines. Apart from their influence on the level of lipids, they are also responsible for inflammatory conditions, oxidative stress, insulin resistance and atherosclerosis [32,64]. Waist circumference is inextricably linked with the visceral adipose tissue content as well as the mass of total adipose tissue in the organism. Such accumulation of adipose tissue causes increased concentration of free fatty acids and leads to hyperinsulinemia and insulin resistance. In addition, it contributes to an increased risk of the occurrence of dyslipidemia, arterial hypertension, type 2 diabetes mellitus, cardiovascular diseases, and MetS $[32,34,65]$.

Results of studies concerning Body Mass Index (BMI) indicate that its values are lower in smokers than in nonsmokers [66]. On the other hand, the authors point to the fact that an increase in BMI in the group of smokers can be related to the frequency of smoking and alcohol consumption as well as the lack of physical activity [66-68]. Moreover, the research demonstrated that nicotine decreases appetite and energy requirements as well as increases the rest metabolic rate [69]. Despite the fact that many studies indicate that BMI is lower in smokers than in nonsmokers, the distribution of adipose tissue is of key significance. An analysis of waist circumference only or the waist-hip ratio (WHR) instead of BMI suggests that smoking cigarettes favors greater accumulation of visceral adipose tissue [65,70].

For many years, research has been conducted on the influence of smoking on the development of abdominal obesity and higher WHR values [24,71-76]. Differences in the occurrence of abdominal obesity are observed also between the sexes [70]. According to researchers, the significantly more frequent central accumulation of adipose tissue in women connected with smoking can result from redistribution of tissue from the buttock and thigh area to the abdominal part or from amyotrophy [70]. Women are characterized by a greater content of adipose tissue, and that is why it is possible that nicotine causes greater fat utilization than in men. The mechanisms can concern differences in sex steroid levels in the serum, cortisol level in the plasma, occurrence of insulin resistance as well as other factors, i.e, the level of physical activity, diet, alcohol consumption, and stress level [68,70].

Research conducted on rats demonstrated that exposure to nicotine contributes to significant adipocytes hypertrophy with increased expression of transcription factors of proadipogenic genes. Such factors include the peroxisome proliferator activated receptor $\gamma$ (PPAR- $\gamma$ ). The result of the aforementioned situation is an increase in body weight and accumulation of adipose tissue [77]. The creation of mature adipocytes is also influenced by oxidative stress [64,78]. Research conducted on mice demonstrated that during exposure to heavy smoking, increased activity of glutathione peroxidase in adipose tissue was reported, which can suggest an increase in oxidative stress inside it [79]. An analysis of other compounds that appear in cigarettes (i.e, carbon oxide, PAHs) also demonstrated their influence on increased lipolysis and adipokine secretion disorders. Such changes increase the risk of occurrence of cardiovascular diseases as well as metabolic diseases and their risk factors [80-82].

So far not much has been learnt about the influence of e-cigarettes on adipose tissue and adipocyte functions. The first such research was conducted by Zagoriti et al. [33]. It compared the influence of traditional cigarettes, e-cigarettes, and heated tobacco products on the differentiation of preadipocytes into beige adipocytes [33]. The increased activity of this kind of adipocytes (so-called thermogenic ones) was suggested as a means of reducing obesity and metabolic disorders. It was demonstrated that the extract of traditional cigarettes, as opposed to the other two extracts, significantly disrupted the differentiation of preadipocytes into beige adipocytes, which can influence the metabolic function of adipose tissue [33]. In turn, the results of research on e-cigarettes conducted on mice demonstrated that pure nicotine did not fully answer for lower body weight [83]. Further studies involving exposure of mice to equivalent nicotine doses, through inhaling e-cigarette or traditional cigarette fumes, did not show any influence on the body weight reduction in those exposed to e-cigarettes. It can suggest 
that it is other compounds in cigarettes that can participate in reducing body weight while smoking traditional cigarettes [84]. On the other hand, opposite results were obtained by El Goli et al. [48] and Werley et al. [85] in their research on rats.

The current possibility to substitute traditional cigarettes with e-cigarettes is responsible for the existence of the so-called "dual users", who in want of quitting smoking start using e-cigarettes. In a study conducted by Kim et al. [37] among dual users and among persons smoking traditional cigarettes, it was shown that average waist circumference as well as the frequency of its occurrence were significantly higher than among people smoking both kinds of cigarettes. It should be emphasized that the long-term effects of such dual use are not well known yet.

Problems in establishing the influence of vaping e-cigarettes on obesity may stem from the fact that some people who are currently vaping e-cigarettes are former traditional cigarette smokers. Those errors were evaded in a research by Polosa et al. [86], who subjected people vaping e-cigarettes who had never smoked before to an observation that lasted 3.5 years. The obtained results did not demonstrate any significant changes in body weight in relation to the output value as well as in relation to the nonsmoking group. No significant differences were reported among people who used e-liquids containing nicotine either [86]. However, the very small size of the research group and the very young age of the researched persons were limiting factors of this study. On the other hand, Lanza et al. [87] indicated that e-cigarettes are growing in popularity, especially among young people. Members of this group often adjust their behavior to their peers in order to maximize social acceptance or minimize depressive disorders caused by peer exclusion [87]. In a study conducted by Delk et al. [88], the existence of positive correlation between the occurrence of obesity in a group of boys who smoked both traditional cigarettes and e-cigarettes was reported. However, no such correlation was reported in the group of girls. Disturbing reports concerning smoking among the youth are also provided by the research conducted by Cho et al. [89] among American teenagers. It was demonstrated that girls who perceived themselves as overweight significantly more often smoked e-cigarettes or were dual users [90].

It needs to be emphasized the vaping is a phenomenon that is currently causing controversies. There is scientific research that indicates it helps reduce the risk of increase in body weight in people who want to quit smoking and/or supports body weight control. Probably, it can stem from additional factors as well, such as taste, physical sensations in the mouth, and behavioral changes [90,91]. Perception of smoking as a factor that helps control body weight was analyzed in a study conducted by Rhoades et al. [92]. It was demonstrated that the claim that e-cigarettes help control body weight was rare. The most uncertain group included adults who smoked both e-cigarettes and traditional ones, though if such an observation was reported, it was more often among people who had used e-cigarettes [92] (Table 5).

Table 5. The impact of electronic cigarettes use and tobacco smoke exposure on abdominal obesity.

\begin{tabular}{|c|c|c|c|c|c|}
\hline Type of Study & $\begin{array}{l}\text { Participants/ } \\
\text { Rodents/ } \\
\text { Type of Cells }\end{array}$ & Country & $\begin{array}{c}\text { Exposure } \\
\text { Assessment }\end{array}$ & Results & Reference \\
\hline In vitro-cells & $\begin{array}{l}\text { Mouse embryo } \\
\text { 3T3-L1 } \\
\text { pre-adipocytes } \\
{\text { (ATCC }{ }^{\circledR} \text { CL-173 }}^{\mathrm{TM}}, \\
\text { ATCC, } \\
\text { Manassas, VA, } \\
\text { USA). }\end{array}$ & United States & $\begin{array}{l}\text { Exposure to cigarette } \\
\text { smoke, electronic } \\
\text { cigarettes and heated } \\
\text { tobacco products. }\end{array}$ & $\begin{array}{l}\text { No differences in } \\
\text { body mass, } \\
\text { E-cigarettes and } \\
\text { heated tobacco } \\
\text { products impact on } \\
\text { the differentiation of } \\
\text { preadipocytes into } \\
\text { beige adipocytes } \\
p<0.01 .\end{array}$ & Zagoriti et al. [33] \\
\hline
\end{tabular}


Table 5. Cont

\begin{tabular}{|c|c|c|c|c|c|}
\hline Type of Study & $\begin{array}{l}\text { Participants/ } \\
\text { Rodents/ } \\
\text { Type of Cells }\end{array}$ & Country & $\begin{array}{c}\text { Exposure } \\
\text { Assessment }\end{array}$ & Results & Reference \\
\hline \multicolumn{6}{|c|}{ E-CIGARETTES } \\
\hline Animal & $\begin{array}{l}\text { Male Wistar } \\
\text { rats }\end{array}$ & Tunisia & $\begin{array}{l}\text { E-liquid with or } \\
\text { without nicotine and } \\
\text { nicotine alone } \\
(0.5 \mathrm{mg} / \mathrm{kg} \text { of body } \\
\text { weight) were } \\
\text { administered } \\
\text { intraperitoneally } \\
\text { during } 28 \text { days. }\end{array}$ & $\begin{array}{l}\text { Increase risk of } \\
\text { obesity, } p>0.05 \text {. }\end{array}$ & El Goli et al. [46] \\
\hline Animal & $\begin{array}{c}\text { Neonatal } \\
\text { C57BL/6J mice }\end{array}$ & United States & $\begin{array}{l}\text { Exposure to } \\
\text { e-cigarettes for the } \\
\text { first } 10 \text { days of life; } \\
\text { e-cigarette cartridges } \\
\text { contained either } 1.8 \% \\
\text { nicotine in propylene } \\
\text { glycol (PG) or PG } \\
\text { vehicle alone; plasma } \\
\text { and urine cotinine } \\
\text { measurements. }\end{array}$ & $\begin{array}{l}\text { No differences for } \\
\text { pure nicotine of body } \\
\text { weight, } p>0.05 \text {. }\end{array}$ & $\begin{array}{c}\text { McGrath-Morrow et al. } \\
{[83]}\end{array}$ \\
\hline Animal & $\begin{array}{c}\text { Male BALB/cJ } \\
\text { mice (Charles } \\
\text { River, Calco, } \\
\text { Como), } 183 \\
\text { month-old. }\end{array}$ & Italy & $\begin{array}{l}\text { Exposure to the } \\
\text { smoke of } 21 \\
\text { cigarettes or e- } \\
\text { cigarette vapor } \\
\text { containing } 16.8 \mathrm{mg} \text { of } \\
\text { nicotine delivered by } \\
\text { means of a } \\
\text { mechanical } \\
\text { ventilator for three } \\
\text { 30-min sessions/day } \\
\text { for seven weeks. }\end{array}$ & $\begin{array}{c}\text { No differences in } \\
\text { body weight, } \\
p>0.05 .\end{array}$ & Ponzoni et al. [84] \\
\hline Human & $\begin{array}{c}\text { Male } \\
\text { participants } \\
(n=7505, \\
\text { aged }>19 \text { years }) .\end{array}$ & $\begin{array}{l}\text { Republic of } \\
\text { Korea }\end{array}$ & Urinary cotinine & $\begin{array}{c}\text { Increase of waist } \\
\text { circumference, } 2.26 \text {, } \\
95 \% \mathrm{ci}=1.31-3.91 \\
\quad p=0.003\end{array}$ & Kim et al. [37] \\
\hline Human & $\begin{array}{c}\text { Participants } \\
(n=16, \\
\text { aged } \geq 18 \text { years), } \\
\text { prospective } \\
\text { 3.5-year study. }\end{array}$ & Italy & Questionnaire & $\begin{array}{c}\text { No differences in } \\
\text { body weight, } \\
p=0.95 .\end{array}$ & Polosa et al. [86] \\
\hline Human & $\begin{array}{l}\text { Participants } \\
(n=2733) \\
\text { students in the } \\
7 \text { th, } 9 \text { th, } \\
\text { and 11th } \\
\text { grades. }\end{array}$ & United States & Questionnaire & $\begin{array}{c}\text { Increase of weight in } \\
\text { boys AOR = 3.45, } \\
95 \% \mathrm{CI}=1.34,8.33 \\
p<0.05\end{array}$ & Delk et al. [88] \\
\hline
\end{tabular}


Table 5. Cont.

\begin{tabular}{|c|c|c|c|c|c|}
\hline Type of Study & $\begin{array}{l}\text { Participants/ } \\
\text { Rodents/ } \\
\text { Type of Cells }\end{array}$ & Country & $\begin{array}{c}\text { Exposure } \\
\text { Assessment }\end{array}$ & Results & Reference \\
\hline \multicolumn{6}{|c|}{ TOBACCO SMOKE } \\
\hline Animal & $\begin{array}{c}\text { Female and } \\
\text { male Sprague } \\
\text { Dawley OFA } \\
\text { rat. }\end{array}$ & Switzerland & $\begin{array}{l}\text { Nicotine or saline } \\
\text { was infused } \\
\text { subcutaneously via } \\
\text { Alzet } \\
\text { osmotic mini-pumps; } \\
\text { cotinine and other } \\
\text { principal metabolites } \\
\text { of nicotine in the } \\
\text { serum. }\end{array}$ & $\begin{array}{l}\text { Increase postnatal } \\
\text { body weight after } \\
\text { perinatal exposure to } \\
\text { nicotine, } p<0.05 \text {. }\end{array}$ & Somm et al. [77] \\
\hline Animal & $\begin{array}{c}\text { Participants } \\
(n=69,000 \text { men } \\
\text { and women } \\
\text { from } 42 \\
\text { populations } \\
\text { participating in } \\
\text { the first WHO } \\
\text { MONICA } \\
\text { survey, } \\
\text { aged 35-64 years). }\end{array}$ & Finland & Questionnaire & $\begin{array}{c}\text { Decrease of BMI, } \\
\quad p<0.05 .\end{array}$ & Molarius et al. [66] \\
\hline Human & $\begin{array}{c}\text { Male } \\
\text { participants } \\
(n=1122, \\
\text { aged } 19-102 \text { years })\end{array}$ & United States & Questionnaire & $\begin{array}{c}\text { Increase of body } \\
\text { mass and BMI, } \\
p<0.05\end{array}$ & Shimokata et al. [72] \\
\hline Human & $\begin{array}{l}\text { Participants } \\
\quad(n=1948, \\
\text { aged } 50-79 \text { years }) .\end{array}$ & United States & Questionnaire & $\begin{array}{c}\text { Increase of BMI and } \\
\text { WHR, } p<0.05\end{array}$ & $\begin{array}{l}\text { Barrett-Connor et al. } \\
{[71]}\end{array}$ \\
\hline Human & $\begin{array}{l}\text { Participants } \\
\quad(n=2341, \\
\text { aged 55-85 years }) .\end{array}$ & Netherlands & Questionnaire & $\begin{array}{c}\text { Increase of WHR } \\
p=0.01 \text { and BMI } \\
p>0.05 .\end{array}$ & Visser et al. [74] \\
\hline Human & $\begin{array}{l}\text { Participants } \\
\quad(n=9047, \\
\text { aged } 16-74 \text { years }) .\end{array}$ & Scotland & Questionnaire & $\begin{array}{c}\text { Increase of WHR } \\
\text { and waist } \\
\text { circumference } \\
\text { among women, } \\
p<0.001 ; \\
\text { Decrease of hip } \\
\text { circumference } \\
\text { among men } p=0.001 \\
\text { and BMI } p>0.05 \text {. }\end{array}$ & $\begin{array}{c}\text { Akbartabartoori et al. } \\
{[70]}\end{array}$ \\
\hline Human & $\begin{array}{l}\text { Participants } \\
(n=6123, \\
\text { aged 35-75years, } \\
\text { Caucasians) }\end{array}$ & Switzerland & Questionnaire & $\begin{array}{c}\text { Increase of } \\
\text { abdominal obesity } \\
\text { among men: } p=0.03 \\
\text { and women } p<0.01 \text {. }\end{array}$ & Clair et al. [75] \\
\hline Human & $\begin{array}{c}\text { Participants } \\
(n=487,527, \\
\text { aged } 30-79 \text { years })\end{array}$ & China & Questionnaire & $\begin{array}{c}\text { Increase of WHR, } \\
\text { waist circumference, } \\
\text { and waist } \\
\text { circumference } \\
\text { /height ratio (WHTR) } \\
p<0.001 .\end{array}$ & Lv et al. [76] \\
\hline
\end{tabular}

\section{Arterial Hypertension}

Another criterion of MetS diagnosis is higher arterial pressure. Arterial hypertension is one of the most common factors that are responsible for the risk of development of heart conditions. 
The renin-angiotensin system is responsible for the regulation of arterial pressure. Many studies indicate that nicotine activates the sympathetic nervous system, releases noradrenaline and adrenaline, which cause nervous stimulation that can last up to 24 hours. Moreover, it inhibits aldosterone synthesis in adrenal glands while causing decreased aldosterone excretion [93]. An overview of sources available on the topic of the influence of traditional cigarettes indicates an increase in values of arterial pressure in smokers [24,94]. In the case of smoking e-cigarettes, the results are ambiguous.

The research conducted by Farsalinos et al. [94] demonstrated that short-term e-cigarette using caused a fractional increase in diastolic blood pressure. However, taking into account the time immediately after smoking, both the systolic and diastolic blood pressure, as well as the heart rate, were significantly elevated. According to the authors, nicotine from e-cigarettes was absorbed to a smaller degree, and that is why they did not show unfavorable influence on the heart function [94].

Also, in the study conducted by Yan et al. [93], a lower nicotine content was reported in the blood of persons vaping e-cigarettes than in the case of people smoking traditional cigarettes (Marlboro ${ }^{\circledR}$ ), which contributed to a smaller increase in arterial pressure and heart rate in this group.

Research by Vlachopoulos et al. [95] was conducted among people of $30 \pm 8$ years of age without cardiovascular risk. The subject of analysis was arterial pressure measured in 4 sessions: smoking traditional cigarettes and e-cigarettes for 5 minutes, 30 minutes of vaping e-cigarettes, and sham procedure that lasted 60 minutes [95]. The analysis of the obtained results did not show any differences in all the readings between the sessions, while the systolic and diastolic arterial pressure values as well as the heart rate increased both during smoking traditional cigarettes and e-cigarettes [95].

Very significant results were obtained in the research conducted by Polosa et al. [86]. During a 3.5 years' observation of a group of young people ( $29.7 \pm 6$ years of age), daily e-cigarette users, who had never smoked before, no significant changes in the heart rate and arterial pressure values were demonstrated in comparison with the control group, who had never smoked any kind of cigarettes [86].

In turn, in a study conducted by Franzen et al. [96], persons vaping e-cigarettes and traditional cigarettes were subjected to a $2 \mathrm{~h}$ observation immediately after having smoked a cigarette. The analysis of the obtained results demonstrated that systolic blood pressure increased for up to 45 minutes after the person had stopped using an e-cigarette containing nicotine and for ca. 15 minutes in the case of normal cigarettes. No significant changes in arterial pressure values in the first hour of observation were reported for e-cigarettes. A similar correlation was demonstrated for heart rate readings [96].

Research in that field was also conducted by Antoniewicz et al. [97] to assess acute influence of inhaling e-cigarettes with nicotine and without it within the period of 0,2 , and 4 hours after exposure. A significant increase in heart rate was reported in the case of vaping e-cigarettes containing nicotine and an increase in arterial blood pressure in both analyzed cases [97].

In the study of Arastoo et al. [98] among 100 electronic and traditional smokers, including chronic smokers, the baseline heart rate variability as well as hemodynamics (blood pressure and heart rate) were analyzed. In this research, the authors hypothesized that the changes in these parameters are caused by nicotine, and not by the non-nicotine components of the e-cigarette aerosol. Based on the conducted research, it was shown that people who were chronic smokers of both types of cigarettes had a similar level of heart rate variability. When assessing the effect of vaping e-cigarettes, a sharp increase in blood pressure and heart rate was noticed only after the use of e-cigarettes with nicotine, which confirmed the hypothesis [98].

An interesting study was also conducted by George et al. [99] on a group of people of $\geq 18$ of age, who had been smoking $\geq 15$ cigarettes for $\geq 2$ years. During the study, the examined persons changed to using e-cigarettes with or without nicotine. The analysis of the obtained results demonstrated that once both groups of e-cigarette smokers had been combined, a greater decrease in systolic blood pressure was reported than in the group of traditional smokers.

Abnormalities in heart rate during vaping e-cigarettes in comparison with nonsmokers were also demonstrated by Moheimani et al. [58]. Importantly, the authors indicate that it was not caused by the nicotine content in the e-cigarette liquid, because it was untraceable in the plasma of the 
examined persons. At the same time, they emphasize that it is nicotine metabolites that can produce adverse effects leading to a greater risk of cardiovascular diseases among people smoking this type of cigarettes [58].

E-cigarettes are very often chosen when a person wants to quit smoking traditional cigarettes. In a 12 month prospective randomized research conducted by Caponetto et al. [100], the researchers subjected 300 participants divided into 3 groups to an analysis. Study groups were given nicotine refill cartridges: (i) $7.2 \mathrm{mg}$ for 12 weeks; (ii) $7.2 \mathrm{mg}$ for 6 weeks and $5.4 \mathrm{mg}$ for another 6 weeks. The control one (iii) was given cartridges without nicotine for 12 weeks. The analysis of the obtained results demonstrated a decrease in the frequency of smoking in each group. However, what is important is the fact that within the duration of the study, no significant changes in systolic and diastolic pressure or heart rate were demonstrated. Moreover, no differences between the analyzed groups were revealed [100]. In turn, in a continuation of that study, conducted by Farsalinos et al. [101], an additional classification of constant smoking phenotype was made, in which people were divided into those who quitted smoking in full, those who limited the number of smoked cigarettes and those in whose case quitting ended in failure. It was demonstrated that persons who limited or quitted smoking and changed to e-cigarettes were characterized by lower systolic arterial blood pressure. This effect was especially visible in persons with elevated values at the beginning of the examination [101].

It has to be taken into account that e-cigarettes, by contributing to an increased sympathetic heart activity, can be also responsible for increased oxidative stress, which will cause an increased cardiovascular risk. Moreover, the increased oxidative stress and inflammatory conditions will induce the development of atherosclerosis (Table 6).

Table 6. The impact of electronic cigarettes use and tobacco smoke exposure on arterial hypertension.

\begin{tabular}{|c|c|c|c|c|c|}
\hline Type of Study & $\begin{array}{l}\text { Participants/ } \\
\text { Rodents/ } \\
\text { Type of Cells }\end{array}$ & Country & Exposure Assessment & Results & Reference \\
\hline \multicolumn{6}{|c|}{ E-CIGARETTES } \\
\hline Human & $\begin{array}{c}\text { Participants } \\
\quad(n=42, \\
\text { aged } 21-45 \text { years }) .\end{array}$ & United States & $\begin{array}{l}\text { Questionnaire, plasma } \\
\text { cotinine }\end{array}$ & $\begin{array}{c}\text { Increase of heart } \\
\text { rate, mean SEM } 1.37 \\
{[0.19], p=0.05 .}\end{array}$ & Moheimani et al. [58] \\
\hline Human & $\begin{array}{c}\text { Participants } \\
(n=23, \\
\text { aged 23-58 years }) .\end{array}$ & United States & $\begin{array}{c}\text { Two commercial } \\
\text { products that contain } \\
16 \mathrm{mg} / \mathrm{mL}(1.6 \%) \\
\text { nicotine and three } \\
\text { non-commercial } \\
\text { products that contain } \\
24 \mathrm{mg} / \mathrm{mL}(2.4 \%) \\
\text { nicotine, in the } \\
\text { cartomizer device format } \\
\text { attached to rechargeable } \\
\text { batteries. In comparison } \\
\text { Marlboro Gold King Size } \\
0.8 \text { mg per cigarette. }\end{array}$ & $\begin{array}{l}\text { Increase of systolic } \\
(p=0.04) \text { and } \\
\text { diastolic }(p=0.0001) \\
\text { blood pressure (five } \\
\text { e-cigs vs. } \\
\text { one Marlboro }{ }^{\circledR} \\
\text { cigarette). }\end{array}$ & Yan et al. [93] \\
\hline Human & $\begin{array}{c}\text { Participants } \\
(n=76, \\
\text { aged } 36 \pm 5 \text { years }) .\end{array}$ & Greece & $\begin{array}{l}\text { Commercially-available } \\
\text { tobacco cigarette: } \\
\text { nicotine }(1.0 \mathrm{mg}), \\
\text { tar }(10 \mathrm{mg}) \text { and carbon } \\
\text { monoxide }(10 \mathrm{mg}) \text { yields, } \\
\text { and electronic cigarette, } \\
\text { commercially-available } \\
\text { device, with liquid } \\
\text { containing } 11 \mathrm{mg} / \mathrm{mL} \\
\text { nicotine concentration. }\end{array}$ & $\begin{array}{c}\text { Increase of systolic } \\
(p<0.001) \text { and } \\
\text { diastolic }(p=0.079) \\
\text { blood pressure; } \\
\text { Increase of heart } \\
\text { rate }(p<0.001)\end{array}$ & Farsalinos et al. [94] \\
\hline
\end{tabular}


Table 6. Cont.

\begin{tabular}{|c|c|c|c|c|c|}
\hline Type of Study & $\begin{array}{l}\text { Participants/ } \\
\text { Rodents/ } \\
\text { Type of Cells }\end{array}$ & Country & Exposure Assessment & Results & Reference \\
\hline \multicolumn{6}{|c|}{ E-CIGARETTES } \\
\hline Human & $\begin{array}{l}\text { Participants } \\
\quad(n=24, \\
\text { aged } 30 \pm 8 \text { years }) \\
\text { smokers free of } \\
\text { cardiovascular } \\
\text { risk factors }\end{array}$ & Greece & $\begin{array}{l}4 \text { separate occasions } \\
\text { (total } 96 \text { sessions): }(1) \\
\text { tobacco cigarette over } \\
5 \mathrm{~min} \text {; (2) e-cigarette over } \\
5 \mathrm{~min} \text {; (3) e-cigarette for } \\
\text { a period of } 30 \text { min and } \\
\text { (4) nothing (sham } \\
\text { procedure) for } 60 \mathrm{~min} .\end{array}$ & $\begin{array}{c}\text { Increase of systolic } \\
\text { and diastolic blood } \\
\text { pressure } p>0.05 ; \\
\text { Increase of heart } \\
\text { rate } p<0.05\end{array}$ & $\begin{array}{l}\text { Vlachopoulos et al. } \\
\text { [95], }\end{array}$ \\
\hline Human & $\begin{array}{c}\text { Participants } \\
\quad(n=15, \\
\text { aged } 22.9 \pm 3.5 \text { year })\end{array}$ & Germany & $\begin{array}{l}\text { (1) Smoking a cigarette } \\
\text { and inhaling into the } \\
\text { lungs, (2) Vaping an } \\
\text { e-cigarette with nicotine } \\
\text { and (3) Vaping an } \\
\text { e-cigarette without } \\
\text { nicotine. }\end{array}$ & $\begin{array}{l}\text { Increase of systolic } \\
\text { and diastolic blood } \\
\text { pressure } p<0.05 ; \\
\text { Increase of heart } \\
\text { rate (with nicotine } \\
\text { e-cig) } p<0.05 \text {. }\end{array}$ & Franzen et al. [96] \\
\hline Human & $\begin{array}{c}\text { Participants } \\
(n=17 \\
\text { aged } 26 \pm 3 \text { year }) .\end{array}$ & Sweden & $\begin{array}{l}\text { The e-liquid base } \\
\text { consisted primarily of } \\
49.4 \% \text { propylene glycol, } \\
44.4 \% \text { vegetable glycerin, } \\
\text { and } 5 \% \text { ethanol without } \\
\text { any added flavorings. } \\
\text { Premixed e-liquids with } \\
\text { and without added } \\
\text { nicotine were used } \\
\text { (19 mg/mL and } 0 \mathrm{mg} / \mathrm{mL} \\
\text { resp). Inhaled } 30 \text { puffs } \\
\text { from the e-cigarette for } \\
30 \mathrm{~min}, \text { with each puff } \\
\text { lasting approximately } \\
\text { three seconds. }\end{array}$ & $\begin{array}{l}\text { Increase of systolic } \\
\text { and diastolic blood } \\
\text { pressure, } p<0.001 ; \\
\text { Increase of heart } \\
\text { rate, } p=0.015\end{array}$ & $\begin{array}{c}\text { Antoniewicz et al. } \\
\text { [97] }\end{array}$ \\
\hline Human & $\begin{array}{c}\text { Participants } \\
\quad(n=100, \\
\text { aged } 21-45 \text { year }) .\end{array}$ & United States & $\begin{array}{l}\text { E-cigarette-users after } \\
\text { using an e-cigarette with } \\
\text { nicotine, e-cigarette } \\
\text { without nicotine, } \\
\text { nicotine inhaler, } \\
\text { or sham-vaping } \\
\text { (control); nicotine and } \\
\text { cotinine plasma levels. }\end{array}$ & $\begin{array}{c}\text { Increase of systolic } \\
p=0.0001 \text { and } \\
\text { diastolic } p=0.002 \\
\text { blood pressure, } \\
\text { Increase of heart rate } \\
\quad p<0.0001 .\end{array}$ & Arastoo et al. [98] \\
\hline Human & $\begin{array}{l}\text { Participants who } \\
\text { were willing to } \\
\text { quit smoking } \\
\quad(n=114, \\
\text { aged } \geq 18 \text { years). }\end{array}$ & $\begin{array}{l}\text { United } \\
\text { Kingdom }\end{array}$ & $\begin{array}{l}\text { E-cigarette containing } \\
16 \mathrm{mg} \text { nicotine or } \\
\text { nicotine-free e-cigarette } \\
\text { plus nicotine flavoring. }\end{array}$ & $\begin{array}{c}\text { Increase of blood } \\
\text { pressure: } \leq 20 \\
\text { pack-years } p=0.59 \\
\text { but }>20 \text { pack-years } \\
p=0.04 ; \\
\text { Increase of heart } \\
\text { rate: } \leq 20 \text { pack-years } \\
p=0.03 ; \\
\text { Decrease of heart } \\
\text { rate: }>20 \text { pack-years } \\
p=0.02 .\end{array}$ & George et al. [99] \\
\hline Human & $\begin{array}{l}\text { Participants who } \\
\text { were willing to } \\
\text { quit smoking } \\
(n=300 \text { aged } \\
44.0 \pm 12.5 \text { years }) \\
\text { smoking } \\
\text { cessation clinic }\end{array}$ & Greece & $\begin{array}{l}\text { E-cigarette kit with } \\
\text { "Original" (2.4\% } \\
\text { nicotine-Group A), } \\
\text { or "Categoria" (1.8\% } \\
\text { nicotine-Group B), } \\
\text { or "Original" without } \\
\text { nicotine ("sweet tobacco" } \\
\text { aroma-Group C) } \\
\text { cartridges. }\end{array}$ & $\begin{array}{c}\text { Decrease of systolic } \\
\text { blood pressure, } \\
p=0.004\end{array}$ & Farsalinos et al. [101] \\
\hline
\end{tabular}


Table 6. Cont.

\begin{tabular}{|c|c|c|c|c|c|}
\hline Type of Study & $\begin{array}{l}\text { Participants/ } \\
\text { Rodents/ } \\
\text { Type of Cells }\end{array}$ & Country & Exposure Assessment & Results & Reference \\
\hline \multicolumn{6}{|c|}{ TOBACCO SMOKE } \\
\hline Human & $\begin{array}{c}\text { Participants } \\
(n=23, \\
\text { aged 23-65 years }) .\end{array}$ & United States & $\begin{array}{c}\text { Two commercial } \\
\text { products that contain } \\
16 \mathrm{mg} / \mathrm{mL}(1.6 \%) \\
\text { nicotine and three } \\
\text { non-commercial } \\
\text { products that contain } \\
24 \mathrm{mg} / \mathrm{mL}(2.4 \%) \\
\text { nicotine, in the } \\
\text { cartomizer device format } \\
\text { attached to rechargeable } \\
\text { batteries. In comparison } \\
\text { to Marlboro Gold King } \\
\text { Size } 0.8 \mathrm{mg} \text { per cigarette. }\end{array}$ & $\begin{array}{c}\text { Increase of systolic } \\
(p=0.02,) \text { and } \\
\text { diastolic }(p<0.05) \\
\text { blood pressure, heart } \\
\text { rate }(p=0.001) \\
\text { among Marlboro }{ }^{\circledR} \\
\text { cigarette users (five } \\
\text { e-cigs vs. } \\
\text { one Marlboro }{ }^{\circledR} \\
\text { cigarette). }\end{array}$ & Yan et al. [93] \\
\hline
\end{tabular}

\section{Conclusions}

Scientific evidence regarding the human health effects of e-cigarettes is limited. It is difficult to compare the traditional cigarettes with e-cigarettes due to the different mechanism of action (electronic mechanism), the form of delivery (vaping), and differences in the content of toxic and carcinogenic substances between tobacco and e-liquid. In comparison to traditional cigarettes, in e-cigarettes mechanism there is no burning. Therefore, it is difficult to consider a comparison of exposure to the tobacco smoke and aerosol generated by e-cigarette in the same volume or same exposure. However, e-cigarettes are considered as nicotine replacement therapy for traditional smokers; therefore it is important to compare the health effects of both forms of exposure. The World Health Organization (WHO) underlines that e-cigarettes still pose a significant health risk. While e-cigarette aerosols may contain fewer toxicants than cigarette smoke, studies evaluating whether e-cigarettes are less harmful than cigarettes are inconclusive. There is still a lack of evidence that they are safe during repeated inhalation in long-term use $[5,6,100]$.

Taking into account all the reviewed data, there are very few studies on the influence of e-cigarettes use on the development of MetS and its components. Among 23 studies, 1 was combined in vitro and in vivo study [33], 6 experimental studies used animal models (Wistar rats, Apoe-/- mice, BALB/cJ mice, C57BL6/J mice) [44,46,55,83-85], and 16 studies concern the impact of e-cigarettes on their users (mostly adult participants aged 18-96 years) [35-38,58,62,86,88,93-99,101].

Taking into account the components of MetS, i.e. abdominal obesity, insulin resistance, dyslipidemia, and elevated arterial blood pressure, the results concerning the influence of e-cigarettes vaping are ambiguous. It follows from the analyzed studies that using e-cigarettes did not affect the development of abdominal obesity, insulin resistance, and elevated arterial blood pressure, but could influence the level of glucose and prediabetic state development, and increased risk of obesity and hypertension. In the case of lipid profile an increase in the TG level was reported, while the influence on the level of concentration of total cholesterol, LDL fraction, and HDL fraction differed.

Most of the available articles reported are limited in their design, methodology, and the used exposure time and lack of long-term follow-up. Animals studies were mostly based on one sex (males). Cohort studies consist mainly of dual smokers (tobacco smokers and e-cigarettes users at once), making it difficult to assess the health effects associated only with e-cigarettes. However, given that most e-cigarette users are dual users (e-cigarettes users and tobacco smokers at once), many of the current research studies were conducted based on their observation. Moreover, some of them included just male participants. 
Therefore, a clear need still remains for the development of new studies regarding e-cigarettes and their impact on MetS risk. Better assessment of e-cigarettes type and use, and further longitudinal studies, are needed to clarify this relationship.

Author Contributions: I.G., M.N., and E.F. prepared the manuscript. Conceptualization: M.N. and E.F.; formal analysis: I.G.; writing and original draft preparation: I.G. and M.N.; writing-review and editing: I.G., M.N., and E.F.; supervision, M.N. and E.F. All authors have read and agreed to the published version of the manuscript.

Funding: This research received no external funding.

Conflicts of Interest: The authors declare no conflict of interest.

\section{References}

1. European Commission: Special Eurobarometer 458. Attitudes of Europeans towards Tobacco and Electronic Cigarettes. Available online: data.europa.eu/euodp/en/data/dataset/S2146_87_1_458_ENG (accessed on 27 November 2017).

2. Romagna, G.; Allifranchini, E.; Bocchietto, E.; Tode-schi, S.; Esposito, M.; Farsalinos, K.E. Cytotoxicity evaluation of electronic cigarette vapor extract on cultured mammalian fibroblasts (ClearStream-LIFE): Comparison with tobacco cigarette smoke extract. Inhal. Toxicol. 2013, 25, 354-361. [CrossRef]

3. Grana, R.; Benowitz, N.; Glantz, S.A. E-cigarettes: A scientific review. Circulation 2014, 129, 1972-1986. [CrossRef] [PubMed]

4. Saitta, D.; Ferro, G.A.; Polosa, R. Achieving appropriate regulations for electronic cigarettes. Ther. Adv. Chronic Dis. 2014, 5, 50-61. [CrossRef]

5. Caponnetto, P.; Russo, C.; Bruno, C.M.; Alamo, A.; Amaradio, M.D.; Polosa, R. Electronic cigarette: A possible substitute for cigarette dependence. Monaldi Arch. Chest Dis. 2013, 79, 12-19. [CrossRef]

6. Britton, J.; Bogdanovica, I. Electronic Cigarettes-A Report Commissioned by Public Health England; Public Health England: London, UK, 2014.

7. Cheng, T. Chemical evaluation of electronic cigarettes. Tob. Control 2014, 23 (Suppl. 2), 11-17. [CrossRef]

8. Margham, J.; McAdam, K.; Forster, M.; Liu, C.; Wright, C.; Mariner, D.; Proctor, C. Chemical Composition of Aerosol from an E-Cigarette: A Quantitative Comparison with Cigarette Smoke. Chem. Res. Toxicol. 2016, 29, 1662-1678. [CrossRef]

9. European Union. Tobacco Products Directive (2014/40/EU). Available online: https://ec.europa.eu/health/ tobacco/products/revision. (accessed on 28 May 2020).

10. Gentzke, A.S.; Creamer, M.; Cullen, K.A.; Ambrose, B.K.; Willis, G.; Jamal, A.; King, B.A. Vital Signs: Tobacco Product Use Among Middle and High School Students—United States, 2011-2018. MMWR Morb. Mortal. Wkly. Rep. 2019, 68, 157-164. [CrossRef]

11. Sun, K.; Liu, J.; Ning, G. Active smoking and risk of metabolic syndrome: A meta-analysis of prospective studies. PLoS ONE 2012, 7, e47791. [CrossRef] [PubMed]

12. Alberti, K.G.; Eckel, R.H.; Grundy, S.M.; Zimmet, P.Z.; Cleeman, J.I.; Donato, K.A.; Fruchart, J.C.; James, W.P.; Loria, C.M.; Smith, S.C., Jr.; et al. Harmonizing the metabolic syndrome: A joint interim statement of the International Diabetes Federation Task Force on Epidemiology and Prevention; National Heart, Lung, and Blood Institute; American Heart Association; World Heart Federation; International Atherosclerosis Society; and International Association for the Study of Obesity. Circulation 2009, 120, 1640-1645. [CrossRef]

13. Ford, E.S.; Giles, W.H.; Dietz, W.H. Prevalence of the metabolic syndrome among US adults: Findings from the third National Health and Nutrition Examination Survey. JAMA 2002, 287, 356-359. [CrossRef]

14. Rinaudo, P.; Wang, E. Fetal Programming and Metabolic Syndrome. Annu. Rev. Physiol. 2012, 74, 107-130. [CrossRef]

15. Park, Y.W.; Zhu, S.; Palaniappan, L.; Heshka, S.; Carnethon, M.R.; Heymsfield, S.B. The metabolic syndrome: Prevalence and associated risk factor findings in the US population from the Third National Health and Nutrition Examination Survey, 1988-1994. Arch. Intern. Med. 2003, 163, 427-436. [CrossRef]

16. Kahn, R.; Buse, J.; Ferrannini, E. The metabolic syndrome: Time for a critical appraisal: Joint statement from the American Diabetes Association and the European Association for the Study of Diabetes. Diabetes Care 2005, 28, 2289-2304. [CrossRef] 
17. Grundy, S.M.; Cleeman, J.I.; Daniels, S.R.; Donato, K.A.; Eckel, R.H.; Franklin, B.A.; Gordon, D.J.; Krauss, R.M.; Savage, P.J.; Smith, S.C., Jr.; et al. Diagnosis and management of the metabolic syndrome: An American Heart Association/National Heart, Lung, and Blood Institute Scientific Statement. Circulation 2005, 112, 2735-2752. [CrossRef] [PubMed]

18. Sattar, N.; McConnachie, A.; Sharper, A.G. Can metabolic syndrome predict cardiovascular disease and diabetes? Outcome data from two prospective studies. Lancet 2008, 371, 1927-1935. [CrossRef]

19. National Cholesterol Education Program (NCEP). Third Report of the National Cholesterol Education Program (NCEP) Expert Panel on Detection, Evaluation, and Treatment of High Blood Cholesterol in Adults (Adult Treatment Panel III) final report. Circulation 2002, 106, 3143-3421. [CrossRef]

20. Matsushita, Y.; Nakagawa, T.; Yamamoto, S.; Takahashi, Y.; Noda, M.; Mizoue, T. Associations of smoking cessation with visceral fat area and prevalence of metabolic syndrome in men: The Hitachi health study. Obesity 2011, 19, 647-651. [CrossRef] [PubMed]

21. Godsland, I.F.; Leyva, F.; Walton, C.; Worthington, M.; Stevenson, J.C. Associations of smoking, alcohol and physical activity with risk factors for coronary heart disease and diabetes in the first follow-up cohort of the Heart Disease and Diabetes Risk Indicators in a Screened Cohort study (HDDRISC-1). J. Intern. Med. 1998, 244, 33-41. [CrossRef]

22. Al-Sawalha, N.A.; Almahmmod, Y.; Awawdeh, M.S.; Alzoubi, K.H.; Khabour, O.F. Effect of waterpipe tobacco smoke exposure on the development of metabolic syndrome in adult male rats. PLoS ONE 2020, 15, e0234516. [CrossRef]

23. Yankey, B.N.; Strasser, S.; Okosun, I.S. A cross-sectional analysis of the association between marijuana and cigarette smoking with metabolic syndrome among adults in the United States. Diabetes Metab. Syndr. 2016, 10 (Suppl. 1), 89-95. [CrossRef]

24. Bermudez, V.; Olivar, L.C.; Torres, W.; Navarro, C.; Gonzalez, R.; Espinoza, C.; Morocho, A.; Mindiola, A.; Chacin, M.; Arias, V.; et al. Cigarette smoking and metabolic syndrome components: A cross-sectional study from Maracaibo City, Venezuela. F1000Research 2019, 7, 565. [CrossRef] [PubMed]

25. Xie, B.; Palmer, P.H.; Pang, Z.; Sun, P.; Duan, H.; Johnson, C.A. Environmental tobacco use and indicators of metabolic syndrome in Chinese adults. Nicotine Tob. Res. 2010, 12, 198-206. [CrossRef] [PubMed]

26. Lin, K.M.; Chiou, J.Y.; Kuo, H.W.; Tan, J.Y.; Ko, S.H.; Lee, M.C. Associations Between Unhealthy Lifestyle Behaviors and Metabolic Syndrome by Gender in Young Adults. Biol. Res. Nurs. 2019, 21, 173-181. [CrossRef] [PubMed]

27. Cheng, E.; Burrows, R.; Correa, P.; Güichapani, C.G.; Blanco, E.; Gahagan, S. Light smoking is associated with metabolic syndrome risk factors in Chilean young adults. Acta Diabetol. 2019, 56, 473-479. [CrossRef] [PubMed]

28. Barranco-Ruiz, Y.; Villa-González, E.; Venegas-Sanabria, L.C.; Chavarro-Carvajal, D.A.; Cano-Gutiérrez, C.A.; Izquierdo, M.; Correa-Bautista, J.E.; González-Ruíz, K.; Ramírez-Vélez, R. Metabolic Syndrome and Its Associated Factors in Older Adults: A Secondary Analysis of SABE Colombia in 2015. Metab. Syndr. Relat. Disord. 2020, 29. [CrossRef]

29. Verhaegen, A.; Van Gaal, L. Vaping and Cardiovascular Health: The Case for Health Policy Action. Curr. Cardiovasc. Risk Rep. 2019, 13, 37. [CrossRef]

30. Song, P.; Zou, M.H. Electronic Cigarettes, Diabetes, and Cardiovascular Disease. EC Diabetes Metab. Res. 2017, SI.01, 3-7.

31. Willi, C.; Bodenmann, P.; Ghali, W.A.; Faris, P.D.; Cornuz, J. Active smoking and the risk of type 2 diabetes: A systematic review and meta-analysis. JAMA 2007, 298, 2654-2664. [CrossRef]

32. Wu, Y.; Song, P.; Zhang, W.; Liu, J.; Dai, X.; Liu, Z.; Lu, Q.; Ouyang, C.; Xie, Z.; Zhao, Z.; et al. Activation of $\mathrm{AMPK} \alpha 2$ in adipocytes is essential for nicotine-induced insulin resistance in vivo. Nat. Med. 2015, 21, 373-382. [CrossRef]

33. Zagoriti, Z.; El Mubarak, M.A.; Farsalinos, K.; Topouzis, S. Effects of Exposure to Tobacco Cigarette, Electronic Cigarette and Heated Tobacco Product on Adipocyte Survival and Differentiation in Vitro. Toxics 2020, 8, 9. [CrossRef]

34. Verhaegen, A.; Van Gaal, L. Do E-cigarettes induce weight changes and increase cardiometabolic risk? A signal for the future. Obes. Rev. 2017, 18, 1136-1146. [CrossRef] [PubMed] 
35. Atuegwu, N.C.; Perez, M.F.; Oncken, C.; Mead, E.L.; Maheshwari, N.; Mortensen, E.M. E-cigarette use is associated with a self-reported diagnosis of prediabetes in never cigarette smokers: Results from the behavioral risk factor surveillance system survey. Drug Alcohol Depend. 2019, 205, 107692. [CrossRef]

36. Lequy, E.; Wiernik, E.; Hourani, I.; Cyr, D.; Nadif, R.; Lemogne, C.; Goldberg, M.; Zins, M.; Airagnes, G. The use of electronic cigarette by smokers and ex-smokers is associated with a poor perceived health status in the population-based Constances cohort. Eur. Respir. J. 2018, 52, OA5221. [CrossRef]

37. Kim, C.Y.; Paek, Y.J.; Seo, H.G.; Cheong, Y.S.; Lee, C.M.; Park, S.M.; Park, D.W.; Lee, K. Dual use of electronic and conventional cigarettes is associated with higher cardiovascular risk factors in Korean men. Sci. Rep. 2020, 10, 5612. [CrossRef] [PubMed]

38. Oh, S.S.; Jang, J.; Lee, D.; Park, E.; Jang, S. Cigarette type or smoking history: Which has a greater impact on the metabolic syndrome and its components? Sci. Rep. 2020, 10, 10467. [CrossRef]

39. Lebovitz, H.E. Insulin resistance: Definition and consequences. Exp. Clin. Endocrinol. Diabetes 2001, 109 (Suppl. 2), 135-148. [CrossRef]

40. Wilcox, G. Insulin and insulin resistance. Clin. Biochem. Rev. 2005, 26, 19-39.

41. Bajaj, M. Nicotine and Insulin Resistance: When the Smoke Clears. Diabetes 2012, 61, 3078-3080. [CrossRef]

42. Benowitz, N.L.; Burbank, A.D. Cardiovascular toxicity of nicotine: Implications for electronic cigarette use. Trends Cardiovasc. Med. 2016, 26, 515-523. [CrossRef]

43. Conklin, D.J.; Schick, S.; Blaha, M.J.; Carll, A.; DeFilippis, A.; Ganz, P.; Hall, M.E.; Hamburg, N.; O’Toole, T.; Reynolds, L.; et al. Cardiovascular injury induced by tobacco products: Assessment of risk factors and biomarkers of harm. A Tobacco Centers of Regulatory Science compilation. Am. J. Physiol. Heart Circ. Physiol. 2019, 316, 801-827. [CrossRef]

44. Orimoloye, O.A.; Uddin, S.M.I.; Chen, L.C.; Osei, A.D.; Mirbolouk, M.; Malovichko, M.V.; Sithu, I.D.; Dzaye, O.; Conklin, D.J.; Srivastava, S.; et al. Electronic cigarettes and insulin resistance in animals and humans: Results of a controlled animal study and the National Health and Nutrition Examination Survey (NHANES 2013-2016). PLoS ONE 2019, 14, e0226744. [CrossRef]

45. Vu, C.U.; Siddiqui, J.A.; Wadensweiler, P.; Gayen, J.R.; Avolio, E.; Bandyopadhyay, G.K.; Biswas, N.; Chi, N.W.; O'Connor, D.T.; Mahata, S.K. Nicotinic acetylcholine receptors in glucose homeostasis: The acute hyperglycemic and chronic insulin-sensitive effects of nicotine suggest dual opposing roles of the receptors in male mice. Endocrinology 2014, 155, 3793-3805. [CrossRef] [PubMed]

46. El Golli, N.; Dkhili, H.; Dallagi, Y.; Rahali, D.; Lasram, M.; Bini-Dhouib, I.; Lebret, M.; Rosa, J.P.; El Fazaa, S.; Allal-El Asmi, M. Comparison between electronic cigarette refill liquid and nicotine on metabolic parameters in rats. Life Sci. 2016, 146, 131-138. [CrossRef] [PubMed]

47. Keith, R.J.; Al Rifai, M.; Carruba, C.; De Jarnett, N.; McEvoy, J.W.; Bhatnagar, A.; Blaha, M.J.; Defilippis, A.P. Tobacco Use, Insulin Resistance, and Risk of Type 2 Diabetes: Results from the Multi-Ethnic Study of Atherosclerosis. PLoS ONE 2016, 11, e0157592. [CrossRef] [PubMed]

48. Axelsson, T.; Jansson, P.A.; Smith, U.; Eliasson, B. Nicotine infusion acutely impairs insulin sensitivity in type 2 diabetic patients but not in healthy subjects. J. Intern. Med. 2001, 249, 539-544. [CrossRef]

49. Hadi, H.A.; Suwaidi, J.A. Endothelial dysfunction in diabetes mellitus. Vasc. Health Risk Manag. 2007, 3, 853-876.

50. Gast, K.B.; Tjeerdema, N.; Stijnen, T.; Smit, J.W.; Dekkers, O.M. Insulin resistance and risk of incident cardiovascular events in adults without diabetes: Meta-analysis. PLoS ONE 2012, 7, e52036. [CrossRef]

51. Sansbury, B.E.; Hill, B.G. Regulation of obesity and insulin resistance by nitric oxide. Free Radic. Biol. Med. 2014, 73, 383-399. [CrossRef]

52. Athyros, V.G.; Katsiki, N.; Doumas, M.; Karagiannis, A.; Mikhailidis, D.P. Effect of tobacco smoking and smoking cessation on plasma lipoproteins and associated major cardiovascular risk factors: A narrative review. Curr. Med. Res. Opin. 2013, 29, 1263-1274. [CrossRef]

53. Zong, C.; Song, G.; Yao, S.; Guo, S.; Yu, Y.; Yang, N.; Guo, Z.; Qin, S. Cigarette smoke exposure impairs reverse cholesterol transport which can be minimized by treatment of hydrogen-saturated saline. Lipids Health Dis. 2015, 14, 159. [CrossRef]

54. Friedman, T.C.; Sinha-Hikim, I.; Parveen, M.; Najjar, S.M.; Liu, Y.; Mangubat, M.; Shin, C.S.; Lyzlov, A.; Ivey, R.; Shaheen, M.; et al. Additive effects of nicotine and high-fat diet on hepatic steatosis in male mice. Endocrinology 2012, 153, 5809-5820. [CrossRef] [PubMed] 
55. Hasan, K.M.; Friedman, T.C.; Shao, X.; Parveen, M.; Sims, C.; Lee, D.L.; Espinoza-Derout, J. E-cigarettes and Western Diet: Important Metabolic Risk Factors for Hepatic Diseases. Hepatology 2019, 69, 2442-2454. [CrossRef] [PubMed]

56. Espinoza-Derout, J.; Shao, X.M.; Bankole, E.; Hasan, K.M.; Mtume, N.; Liu, Y.; Sinha-Hikim, A.P.; Friedman, T.C. Hepatic DNA Damage Induced by Electronic Cigarette Exposure Is Associated With the Modulation of NAD +/PARP1/SIRT1 Axis. Front. Endocrinol. 2019, 10, 320. [CrossRef] [PubMed]

57. El Golli, N.; Jrad-Lamine, A.; Neffati, H.; Rahali, D.; Dallagi, Y.; Dkhili, H.; Ba, N.; El May, M.V.; El Fazaa, S. Impact of e-cigarette refill liquid with or without nicotine on liver function in adult rats. Toxicol. Mech. Methods 2016, 26, 419-426. [CrossRef]

58. Moheimani, R.S.; Bhetraratana, M.; Yin, F.; Peters, K.M.; Gornbein, J.; Araujo, J.A.; Middlekauff, H.R. Increased Cardiac Sympathetic Activity and Oxidative Stress in Habitual Electronic Cigarette Users: Implications for Cardiovascular Risk. JAMA Cardiol. 2017, 2, 278-284. [CrossRef]

59. Lerner, C.A.; Sundar, I.K.; Watson, R.M.; Elder, A.; Jones, R.; Done, D.; Kurtzman, R.; Ossip, D.J.; Robinson, R.; McIntosh, S.; et al. Environmental health hazards of e-cigarettes and their components: Oxidants and copper in e-cigarette aerosols. Environ. Pollut. 2015, 198, 100-107. [CrossRef]

60. Putzhammer, R.; Doppler, C.; Jakschitz, T.; Heinz, K.; Förste, J.; Danzl, K.; Messner, B.; Bernhard, D. Vapours of US and EU Market Leader Electronic Cigarette Brands and Liquids Are Cytotoxic for Human Vascular Endothelial Cells. PLoS ONE 2016, 11, e0157337. [CrossRef]

61. Alzahrani, T.; Pena, I.; Temesgen, N.; Glantz, S.A. Association between Electronic Cigarette Use and Myocardial Infarction. Am. J. Prev. Med. 2018, 55, 455-461, Erratum in 2019, 57, 579-584. [CrossRef]

62. Badea, M.; Gaman, L.; Delia, C.; Ilea, A.; Leașu, F.; Henríquez-Hernández, L.A.; Luzardo, O.P.; Rădoi, M.; Rogozea, L. Trends of Lipophilic, Antioxidant and Hematological Parameters Associated with Conventional and Electronic Smoking Habits in Middle-Age Romanians. J. Clin. Med. 2019, 8, 665. [CrossRef]

63. de Lorenzo, A.; Deurenberg, P.; Pietrantuono, M.; Di Daniele, N.; Cervelli, V.; Andreoli, A. How fat is obese? Acta Diabetol. 2003, 40 (Suppl. 1), 254-257. [CrossRef]

64. Wang, Z.; Wang, D.; Wang, Y. Cigarette Smoking and Adipose Tissue: The Emerging Role in Progression of Atherosclerosis. Mediat. Inflamm. 2017, 2017, 3102737. [CrossRef] [PubMed]

65. Chiolero, A.; Faeh, D.; Paccaud, F.; Cornuz, J. Consequences of smoking for body weight, body fat distribution, and insulin resistance. Am. J. Clin. Nutr. 2008, 87, 801-809. [CrossRef] [PubMed]

66. Molarius, A.; Seidell, J.C.; Kuulasmaa, K.; Dobson, A.J.; Sans, S. Smoking and relative body weight: An international perspective from the WHO MONICA Project. J. Epidemiol. Community Health 1997, 51, 252-260. [CrossRef]

67. Oh, H.S.; Seo, W.S. The compound relationship of smoking and alcohol consumption with obesity. Yonsei Med. J. 2001, 42, 480-487. [CrossRef] [PubMed]

68. Tuovinen, E.; Saarni, S.; Männistö, S.; Borodulin, K.; Patja, K.; Kinnunen, T.H.; Kaprio, J.; Korhonen, T. Smoking status and abdominal obesity among normal- and overweight/obese adults: Population-based FINRISK study. Prev. Med. Rep. 2016, 4, 324-330. [CrossRef]

69. Miyata, G.; Meguid, M.M.; Varma, M.; Fetissov, S.O.; Kim, H.J. Nicotine alters the usual reciprocity between meal size and meal number in female rat. Physiol. Behav. 2001, 74, 169-176. [CrossRef]

70. Akbartabartoori, M.; Lean, M.E.; Hankey, C.R. Relationships between cigarette smoking, body size and body shape. Int. J. Obes. 2005, 29, 236-243. [CrossRef]

71. Barrett-Connor, E.; Khaw, K.T. Cigarette smoking and increased central adiposity. Ann. Intern. Med. 1989, 15, 783-787. [CrossRef]

72. Shimokata, H.; Muller, D.C.; Andres, R. Studies in the distribution of body fat; III. Effect of cigarette smoking. JAMA 1989, 261, 1169-1173. [CrossRef]

73. Lissner, L.; Bengtsson, C.; Lapidus, L.; Bjorkelund, C. Smoking initiation and cessation in relation to body fat distribution based on data from a study of Swedish women. Am. J. Public Health 1992, 82, 273-275. [CrossRef]

74. Visser, M.; Launer, L.J.; Deurenberg, P.; Deeg, D.G. Past and current smoking in relation to body fat distribution in older men and women. J. Gerontol. A Biol. Sci. Med. Sci. 1999, 54, 293-298. [CrossRef] [PubMed] 
75. Clair, C.; Chiolero, A.; Faeh, D.; Cornuz, J.; Marques-Vidal, P.; Paccaud, F.; Mooser, V.; Waeber, G.; Vollenweider, P. Dose-dependent positive association between cigarette smoking, abdominal obesity and body fat: Cross-sectional data from a population-based survey. BMC Public Health 2011, 11, 23. [CrossRef] [PubMed]

76. Lv, J.; Chen, W.; Sun, D.; Li, S.; Millwood, I.Y.; Smith, M.; Guo, Y.; Bian, Z.; Yu, C.; Zhou, H.; et al. China Kadoorie Biobank collaborative group. Gender-specific association between tobacco smoking and central obesity among 0.5 million Chinese people: The China Kadoorie Biobank Study. PLoS ONE 2015, 10, e0124586. [CrossRef] [PubMed]

77. Somm, E.; Schwitzgebel, V.M.; Vauthay, D.M.; Camm, E.J.; Chen, C.Y.; Giacobino, J.P.; Sizonenko, S.V.; Aubert, M.L.; Hüppi, P.S. Prenatal nicotine exposure alters early pancreatic islet and adipose tissue development with consequences on the control of body weight and glucose metabolism later in life. Endocrinology 2008, 149, 6289-6299. [CrossRef] [PubMed]

78. Lee, H.; Lee, Y.J.; Choi, H.; Ko, E.H.; Kim, J.W. Reactive oxygen species facilitate adipocyte differentiation by accelerating mitotic clonal expansion. J. Biol. Chem. 2009, 284, 10601-10609. [CrossRef]

79. Itoh, M.; Tsuji, T.; Nakamura, H. Systemic effects of acute cigarette smoke exposure in mice. Inhal. Toxicol. 2014, 26, 464-473. [CrossRef]

80. Irigaray, P.; Lacomme, S.; Mejean, L.; Belpomme, D. Ex vivo study of incorporation into adipocytes and lipolysis-inhibition effect of polycyclic aromatic hydrocarbons. Toxicol. Lett. 2009, 187, 35-39. [CrossRef]

81. Hosick, P.A.; AlAmodi, A.A.; Storm, M.V.; Gousset, M.U.; Pruett, B.E.; Gray, W., III.; Stout, J.; Stec, D.E. Chronic carbon monoxide treatment attenuates development of obesity and remodels adipocytes in mice fed a high-fat diet. Int. J. Obes. 2014, 38, 132-139. [CrossRef]

82. Dubois-Deruy, E.; Rémy, G.; Alard, J.; Kervoaze, G.; Chwastyniak, M.; Baron, M.; Beury, D.; Siegwald, L.; Caboche, S.; Hot, D.; et al. Modelling the Impact of Chronic Cigarette Smoke Exposure in Obese Mice: Metabolic, Pulmonary, Intestinal, and Cardiac Issues. Nutrients 2020, 12, 827. [CrossRef]

83. McGrath-Morrow, S.A.; Hayashi, M.; Aherrera, A.; Lopez, A.; Malinina, A.; Collaco, J.M.; Neptune, E.; Klein, J.D.; Winickoff, J.P.; Breysse, P.; et al. The effects of electronic cigarette emissions on systemic cotinine levels, weight and postnatal lung growth in neonatal mice. PLoS ONE 2015, 10, e0118344. [CrossRef]

84. Ponzoni, L.; Morettia, M.; Salaa, M.; Fasolia, F.; Mucchiettoa, V. Different physiological and behavioural effects of e-cigarette vapour and cigarette smoke in mice. Eur. Neuropsychopharmacol. 2015, 25, 1775-1786. [CrossRef] [PubMed]

85. Werley, M.S.; Kirkpatrick, D.J.; Oldham, M.J.; Jerome, A.M.; Langston, T.B.; Lilly, P.D.; Smith, D.C.; Mckinney, W.J., Jr. Toxicological assessment of a prototype e-cigaret device and three flavor formulations: A 90-day inhalation study in rats. Inhal. Toxicol. 2016, 28, 22-38. [CrossRef] [PubMed]

86. Polosa, R.; Cibella, F.; Caponnetto, P.; Maglia, M.; Prosperini, U.; Russo, C.; Tashkin, D. Health impact of E-cigarettes: A prospective 3.5-year study of regular daily users who have never smoked. Sci. Rep. 2017, 7, 13825. [CrossRef] [PubMed]

87. Lanza, H.I.; Pittman, P.; Batshoun, J. Obesity and cigarette smoking: Extending the link to E-cigarette/vaping use. Am. J. Health Behav. 2017, 41, 338-347. [CrossRef]

88. Delk, J.; Creamer, M.R.; Perry, C.L.; Harrell, M.B. Weight Status and Cigarette and Electronic Cigarette Use in Adolescents. Am. J. Prev. Med. 2018, 54, 31-35. [CrossRef]

89. Cho, B.Y.; Seo, D.C.; Lin, H.C.; Lohrmann, D.K.; Chomistek, A.K.; Hendricks, P.S.; Timsina, L. Adolescent Weight and Electronic Vapor Product Use: Comparing BMI-Based With Perceived Weight Status. Am. J. Prev. Med. 2018, 55, 541-550. [CrossRef]

90. Green, V.R.; Silveira, M.L.; Kimmel, H.L.; Conway, K.P. Body mass index and tobacco-product use among U.S. youth: Findings from wave 1 (2013-2014) of the Population Assessment of Tobacco and Health (PATH) Study. Addict. Behav. 2018, 81, 91-95. [CrossRef]

91. Glover, M.; Breier, B.H.; Bauld, L. Could Vaping be a New Weapon in the Battle of the Bulge? Nicotine Tob. Res. 2017, 19, 1536-1540. [CrossRef]

92. Rhoades, D.A.; Comiford, A.L.; Dvorak, J.D.; Ding, K.; Hopkins, M.; Spicer, P.; Wagener, T.L.; Doescher, M.P. Perceptions of Smoking and Vaping on Weight Control Among Adult American Indians Who Smoke. J. Community Health 2019, 44, 1120-1126. [CrossRef]

93. Yan, X.S.; D'Ruiz, C. Effects of using electronic cigarettes on nicotine delivery and cardiovascular function in comparison with regular cigarettes. Regul. Toxicol. Pharmacol. 2015, 71, 24-34. [CrossRef] 
94. Farsalinos, K.E.; Tsiapras, D.; Kyrzopoulos, S.; Savvopoulou, M.; Voudris, V. Acute effects of using an electronic nicotine-delivery device (electronic cigarette) on myocardial function: Comparison with the effects of regular cigarettes. BMC Cardiovasc. Disord. 2014, 14, 78. [CrossRef] [PubMed]

95. Vlachopoulos, C.; Ioakeimidis, N.; Abdelrasoul, M.; Terentes-Printzios, D.; Georgakopoulos, C.; Pietri, P.; Stefanadis, C.; Tousoulis, D. Electronic Cigarette Smoking Increases Aortic Stiffness and Blood Pressure in Young Smokers. J. Am. Coll. Cardiol. 2016, 67, 2802-2803. [CrossRef] [PubMed]

96. Franzen, K.F.; Willig, J.; Cayo Talavera, S.; Meusel, M.; Sayk, F.; Reppel, M.; Dalhoff, K.; Mortensen, K.; Droemann, D. E-cigarettes and cigarettes worsen peripheral and central hemodynamics as well as arterial stiffness: A randomized, double-blinded pilot study. Vasc. Med. 2018, 23, 419-425. [CrossRef]

97. Antoniewicz, L.; Brynedal, A.; Hedman, L.; Lundbäck, M.; Bosson, J.A. Acute Effects of Electronic Cigarette Inhalation on the Vasculature and the Conducting Airways. Cardiovasc. Toxicol. 2019, 19, 441-450. [CrossRef] [PubMed]

98. Arastoo, S.; Haptonstall, K.P.; Choroomi, Y.; Moheimani, R.S.; Nguyen, K.H.; Tran, E.U.; Gornbein, J.; Middlekauf, H.R. Acute and Chronic Sympathomimetic Effects of E-Cigarette and Tobacco Cigarette Smoking: Role of Nicotine and Non-Nicotine Components. Am. J. Physiol. Heart Circ. Physiol. 2020, 319, 262-270. [CrossRef]

99. George, J.; Hussain, M.; Vadiveloo, T.; Ireland, S.; Hopkinson, P.; Struthers, A.D.; Donnan, P.T.; Khan, F.; Lang, C.C. Cardiovascular Effects of Switching From Tobacco Cigarettes to Electronic Cigarettes. J. Am. Coll. Cardiol. 2019, 74, 3112-3120. [CrossRef]

100. Caponnetto, P.; Campagna, D.; Cibella, F.; Morjaria, J.B.; Caruso, M.; Russo, C.; Polosa, R. Efficiency and safety of an electronic cigarette (ECLAT) as tobacco cigarettes substitute: A prospective 12-month randomized control design study. PLoS ONE 2013, 8, e66317. [CrossRef]

101. Farsalinos, K.; Cibella, F.; Caponnetto, P.; Campagna, D.; Morjaria, J.B.; Battaglia, E.; Caruso, M.; Russo, C.; Polosa, R. Effect of continuous smoking reduction and abstinence on blood pressure and heart rate in smokers switching to electronic cigarettes. Intern. Emerg. Med. 2016, 11, 85-94. [CrossRef]

Publisher's Note: MDPI stays neutral with regard to jurisdictional claims in published maps and institutional affiliations.

(C) 2020 by the authors. Licensee MDPI, Basel, Switzerland. This article is an open access article distributed under the terms and conditions of the Creative Commons Attribution (CC BY) license (http://creativecommons.org/licenses/by/4.0/). 